\title{
Nie sommer nie: Sociohistorical and formal comparative considerations in the rise and maintenance of the modern Afrikaans negation system
}

\author{
Theresa Biberauer \\ Department of Theoretical and Applied Linguistics \\ University of Cambridge \\ England \\ and \\ Department of General Linguistics \\ Stellenbosch University \\ South Africa \\ E-mail: mtb23@cam.ac.uk
}

\begin{abstract}
This article has three major objectives. Firstly, it aims to describe and account for the peculiarity of the modern Afrikaans negative concord marker $n i e_{2}$ in the familiar Western European context. I appeal to Roberge's (2000) diachronic proposals as the initial starting point for this oddness, showing how nie 2 's putative origins as a discourse-oriented particle are synchronically reflected in the modern language, producing, among other things, what appears to be inertness in the context of Jespersen's Cycle. This inertness leads to the interface-driven hypothesis that systems in which a structurally very high element becomes grammaticalised as a sentential Negative Concord element will not progress to the next stage of Jespersen's Cycle, i.e. a structurally very high Negative Concord element will never take over as the "real" negation element. The article's second objective is to demonstrate, on the basis of data from Brazilian Portuguese, Santomé, and a subset of Bantu languages, that the predictions of this hypothesis appear to be correct. At the same time, I show how crucial it is to distinguish the cyclic negation-reinforcing developments associated with Jespersen's Cycle from non-cyclic reinforcement developments; as they may draw on the same lexical resources, this can be a challenging task, particularly where less well-studied languages are the object of investigation. The final part of the article broadens the focus, considering Afrikaans's overall negation profile in the context of negation typology and learnability. The conclusion drawn here is that this system, which owes some of its properties to prescriptive stipulations, is a highly unusual and possibly not even naturally acquirable one.
\end{abstract}

Keywords: Afrikaans, Jespersen's Cycle, learnability, negation, Negative Concord, typology 


\section{Introduction ${ }^{1}$}

This article focuses on Afrikaans negation, a topic on which Hans den Besten wrote a great deal, with - as will become evident from the citations in this article - his characteristic (farahead-of-his-time) lasting insight. Just a month before his untimely death in 2010 , he was due to participate in a colloquium at Utrecht University, marking the successul completion of a Stellenbosch/Utrecht Ph.D. project on Afrikaans negation, Kate Huddlestone's Negative Indefinites in Afrikaans. There, he was slated to give a talk comparing his own ideas about the origins of Afrikaans's clause-final negation-element, nie, with those of his long-time colleague and friend, Paul Roberge. The brief abstract he had submitted for the workshop programme promised new primary historical data-based insights pointing to the correctness of Roberge's hypothesis. In the event, illness prevented Hans from being at the colloquium, so it will never be known what his revised position on the provenance of clause-final nie (henceforth $n_{i e_{2}}$ ) was. What I do know from the conversations I was privileged to have with him over many years on this and other topics is that he would have enjoyed thinking about and debating the idea that modern Afrikaans negation - whatever the precise details of its origins - exhibits a range of properties that mark it out as, fundamentally, a hybrid system and one that differs in very significant ways from familiar Western European systems (see Willis, Lucas and Breitbarth 2013 for overview discussion).

Accordingly, the purpose of this article will be three-fold. Firstly, I will show how different modern Afrikaans's negative concord marker, nie $_{2}$, is to its better studied Western European counterparts and, appealing to Roberge's diachronic proposals, why that should be. As part of this discussion, it will emerge that nie 2 's peculiarities appear, on the one hand, to be putting a brake on cyclic developments that might otherwise be expected - those associated with Jespersen's Cycle - but, on the other hand, that it is also not the case that modern Afrikaans (henceforth Afrikaans) is inert to cyclic change: we do see reinforcing developments, although, strikingly, these are mostly at the sub-clausal level (cf. Biberauer 2009, Huddlestone 2010). The aim of the second part of the article is to highlight the fact that it is important to draw a distinction between "traditional" Jespersen-type cyclic developments, which may lead to the introduction of a new sentential negator, and non-cyclic reinforcement developments of the reinforcing and thus discourse-sensitive type just mentioned. Our focus in this section will be Brazilian Portuguese (BP), like Afrikaans a contact variety which has arisen under complex sociolinguistic circumstances. BP has been said to be in the process of establishing its originally negation-reinforcing element, $n \tilde{a} o-$ which, like $n i e_{2}$, is clause-final - as the neutral sentential negation marker (cf. i.a. Schwegler 1986, 1991; Lipski 2001). Closer investigation, however, shows that this is incorrect (cf. Biberauer and Cyrino 2009a,b), and that the BP developments in fact parallel those currently underway in sub-clausal domains in Afrikaans. This proposal is supported by further evidence from a number of contact varieties, notably Santomé, a Portuguese-based Gulf of Guinea Creole, and also various Bantu languages, all of which share the property of having a clause-final reinforcing negation element. The last part of the article will broaden the focus, considering Afrikaans's overall negation profile in the context of negation typology and learnability, drawing the conclusion that this system, which owes some of its properties to prescriptive stipulations, is a highly unusual and possibly not even naturally acquirable one.

\footnotetext{
${ }^{1}$ The research presented in this article is funded by the European Research Council Advanced Grant No. 269752

"Rethinking Comparative Syntax" (ReCoS). Many people have contributed to it since I first began thinking
} 
The article is structured as follows: Section 2 focuses on the peculiarity of $n i e_{2}$, which is attributed to its origins as a discourse tag (Roberge 2000), and the formal consequences of this, in Western European terms, unusual source. Particularly important here is the fact that the negative developments that we observe in Afrikaans do not appear to be of the familiar Jespersenian type. This leads to a prediction - that clause-final negative concord-markers of the Afrikaans type can never develop into the main (or "real") sentential negation marker in a clause - which is put to the test in Sections 3 and 4, where the focus is first on BP, and then on Santomé and a range of Bantu languages, all of which at first sight seem to undermine the proposed hypothesis, but do not in fact do so. Section 5 turns to "bigger picture" typological and learnability questions, before Section 6 summarises and concludes.

\section{Afrikaans Negation meets Jespersen's Cycle}

\subsection{Background: Afrikaans and its negation system}

There has been considerable debate as to whether Afrikaans - a South African off-shoot of $17^{\text {th }}$ century Dutch, which has been in contact with a wide range of (European and nonEuropean $^{2}$ ) languages throughout its history - should be viewed as the youngest member of the West Germanic family or, instead, as a creolised system of some kind (cf. the den Besten papers collected in van der Wouden 2012, and also i.a. Ponelis 1993, Roberge 1994, Deumert 2004, Hugo 2009, van Rensburg 2012, and Steyn 2014 for overview discussion and references; additionally, note the fact that Afrikaans is one of the languages that features in the online Atlas of Pidgin and Creole Languages, APiCS; http://apics-online.info). This debate is relevant here for two reasons. Firstly, various West Germanic languages - notably, Dutch, German and English - have passed through the much-discussed negative cycle known as Jespersen's Cycle (cf. Jespersen 1917, and van der Auwera 2009, 2010 for overview discussion), developing new sentential negators during the course of their recorded history. Secondly, the Afrikaans negation system has been shown to differ quite substantially from what is found in Dutch varieties or, more generally, in the European languages with which Afrikaans was in contact during its formative period (cf. again Ponelis, Roberge, Deumert and van der Wouden, op.cit, and also, particularly, den Besten 1986 and Roberge 2000).

Let us consider the first of these factors, namely the fact that Afrikaans's West Germanic relatives have all innovated new sentential negation markers in accordance with Jespersen's Cycle (JC). JC is schematised in (1):

$$
\text { I. } \mathrm{NEG}_{1} \ldots \text { II. } \mathrm{NEG}_{1} \ldots\left(\mathrm{NEG}_{2}\right) \text { III. } \mathrm{NEG}_{1} \ldots \mathrm{NEG}_{2} \text { IV. }\left(\mathrm{NEG}_{1}\right) \ldots \mathrm{NEG}_{2} \text { V. NEG }
$$

As (1) shows, JC entails an initially independently occurring sentential negator $\left(\mathrm{NEG}_{1}\right.$; Stage I) which may be optionally and ever more frequently reinforced by a particular element $\left(\mathrm{NEG}_{2}\right.$; Stage II), which may subsequently become obligatory (Stage III), whereafter the original negator $\left(\mathrm{NEG}_{1}\right)$ may become optional (Stage IV), with the reinforcer ultimately taking over and being reanalysed as the uniquely required sentential negation element $\left(\mathrm{NEG}_{3}\right)$; at this point, the

\footnotetext{
${ }^{2}$ French, German, English and seafarer Portugese are the main European languages with which Afrikaans had contact during the $17^{\text {th }}-19^{\text {th }}$ centuries, while Malay and Khoekhoe were the major non-European contact varieties during the same period.
} 
Cycle may then begin again. ${ }^{3}$ Jespersen's own work focused in particular on the considerations leading languages to proceed from Stage II to III, i.e. from having an optional reinforcing element like Old English noht (>ne wiht 'not a whit') or French pas ('step') to having two obligatory negation element (ne ... noht and ne ... pas in Middle English and later Old French, respectively). These he identified as phonological, i.e. phonological weakening of $\mathrm{NEG}_{1}$ necessitates the introduction of a strong reinforcing element. Much subsequent work has, however, highlighted the fact that pragmatic/expressive considerations seem to be primary, with phonological weakening not being a necessary prerequisite for the introduction of reinforcer elements (cf. i.a. Dahl 2001; Schwenter 2002, 2005; Eckardt 2006; Kiparsky and Condoravdi 2006; Poletto 2008a,b; Mosegaard Hansen 2009; Biberauer 2009, 2012a; Larrivée 2010; Meisner, Stark and Völker 2013; Mosegaard Hansen and Visconti 2014). Some of this more recent literature has also highlighted the fact that reinforcers may be distributionally restricted, serving to emphasise particular types of negation rather than negation across-the-board (cf. i.a. Schwenter, Mosegaard Hansen, Mosegaard Hansen and Visconti, and Biberauer op.cit.). The motivations underlying changes in the negation system will be one of the themes to which we will be returning below. For the moment, though, the key point is that the developments that have taken place in Afrikaans's West Germanic relatives might lead us to expect that Afrikaans, too, may undergo similar changes.

On the other hand, though, there are also reasons to wonder whether this will be the case, given how different the Afrikaans negation system is from familiar West Germanic ones. Investigation has shown that none of the European varieties exhibited an obligatorily clausefinal negative reinforcer of the kind required in standard Afrikaans. This is significant as it has become clear that systems in which a reinforcing element surfaces in the immediately postverbal position (cf. pas in French) must be distinguished from those in which the reinforcing element is clause-final (cf. i.a. Bell 2004, who refers to the latter type as "Bipartite Negation with Final Negator/BNF" systems, and deVos and van der Auwera 2013, who illustrate this difference for Bantu; see Section 4.2 below). Furthermore, typological research has also established that VO systems featuring clause-final negators are crosslinguistically very rare indeed, with attested systems mostly confined to just two areas in the world - central Africa and Austronesia (cf. Reesink 2002 and Dryer 2009). Since simple-tense main clauses in Afrikaans are VO (cf. Ek kweek groente - 'I grow vegetables'), it is clear that progression to JC Stage IV/V would give rise to what appears to be a typologically marked system: VONeg, where $\mathrm{Neg}=\mathrm{ni}_{3}$ and $\mathrm{ni}_{3}$ is the innovated "real" sentential negation marker, which developed out of originally reinforcing (Stage II) and then intepretively bleached (Stage III) $n_{i} e_{2}$. This, then, renders Afrikaans a particularly intriguing system to investigate more closely: is it in the process of developing a crosslinguistically even more unusual negation system than the one it already has, or is it resisting the Jespersenian pressures that produced cyclic change in its West Germanic relatives? We return to these points below, particularly in Section 2.3. First, however, we turn our attention to the structure of Afrikaans negated sentences.

As (2-3) show, standard Afrikaans contrasts with standard Dutch in necessarily requiring negative clauses to conclude with clause-final concord-marking nie (as already noted, we will

\footnotetext{
${ }^{3}$ Here and elsewhere we abstract away from the non-trivial question of whether $\mathrm{NEG}_{2}$ and $\mathrm{NEG}_{1}$ at Stages II and IV respectively are in fact semantically and/or syntactically negative or not. For recent discussion of this matter, see i.a. Breitbarth (2009) and Breitbarth and Haegeman (2010, 2014).
} 
consistently mark this final element as nie $_{2}$ to distinguish it from the "real" negator, nie $_{1}$, and we will also gloss it as POL for reasons that will become clearer below): ${ }^{4}$

a. Ik ben niet rijk.
I am not rich

[Dutch]

'I am not rich.'

b. Ek is nie $_{1} r y k$ nie $_{2}$.

[Afrikaans]

$\mathrm{I}$ is not rich POL

'I am not rich.' ( $\neq$ 'I am not not rich.')

(3) a. Zij hebben nooit een auto gehad.

[Dutch]

they have never a car had

'They have never had a car.'

b. Hulle het nooit 'n kar gehad nie $e_{2}$

[Afrikaans]

they have never a car had POL

'They never had a car.'

While Modern Dutch is a Stage I language, then, Standard Afrikaans is Stage III. Viewed from a JC perspective, the question then arises whether there are any signs of progression to Stage IV/V. Progression to a following stage is of course not a given, as the countless stable negation systems attested world-wide - including some which appear to have remained "immune" to JC throughout their history (cf. Willis 2013a for discussion of Slavic) - clearly show. Nevertheless, given the history of the European languages to which Afrikaans is related and with which it has been in contact, the question whether Afrikaans might be susceptible to JC changes is worth posing. Viewed from the perspective of JC, the "traditional" expectation for Afrikaans might be schematised as in (4):

\footnotetext{
${ }^{4}$ For the purposes of this discussion, we will assume that $n i e_{1}$ and $n i e_{2}$ are featurally distinct, i.e. that $n i e_{2}$ is, in the words of our title, nie sommer nie $e_{1}$, i.e. nie $e_{2}$ is not just another instantiation of the original negator, nie $e_{1}$ (cf. Molnárfi 2002 for an analysis along these lines). In other work (cf. Biberauer and Zeijlstra 2012a,b), I have considered the possibility that $n i e_{1}$ and $n i e_{2}$ may be featurally identical - both bearing uninterpretable negative features, [uNEG] - but it is worth noting that this analysis is an underspecification one, in terms of which neither nie $_{1}$ nor nie $_{2}$ have the featural specification - interpretable negation, [iNEG] - of the original sentential negation marker, nie $_{1}$ of JC Stages I and II. In other words, on both analyses, nie is nie sommer nie $_{2}$.

Note that Biberauer (2008) offers a discussion of the haplology contexts in which concord-marking $n^{2} e_{2}$ fails to surface. Significantly, den Besten (1986: 202) was the first to propose that structures in which the expected number of nies fail to surface should be analysed as involving haplology (cf. also Robbers 1992). Both den Besten and Robbers failed to distinguish between $n i e_{1}$ and $n i e_{2}$ in their haplological proposals, however, simply assuming that, wherever two nies surface adjacent to one another, the second is deleted. Where two nie $_{l} \mathrm{~s}$ are adjacent, as in (i), however, haplology fails to occur; it applies exclusively to ie $_{2}$, as one might expect, given recoverability considerations:
}

(i) Hy kom NIE nie $_{1}$ nie $_{2}$ !

he come not not POL

'He is NOT not coming!', i.e. he will be there 
(4)
nie $_{1} \ldots$ nie $_{2} \quad \rightarrow$
$\left(\right.$ nie $\left._{1}\right)$... nie $_{2} \rightarrow$
nie $_{3}$
Modern Afrikaans
Future Afrikaans
i.e. Stage III $\rightarrow$ Stage IV, i.e. $n$ ie $_{1}$ becomes optional, ultimately being replaced by $n i e_{2}$
$\rightarrow$ Stage V nie 3

As Biberauer (2009) shows, however, there are no signs of this development in contemporary Afrikaans. The following section summarises the relevant facts.

\subsection{Negation in contemporary Afrikaans}

\subsubsection{The formal properties of nie $_{2}$ in the context of the Afrikaans negation system}

Significantly in the context of Jespersen's famous characterisation of the circumstances under which reinforcing negation elements are introduced - see (5) below - standard Afrikaans nie ${ }_{1}$ can be shown to be strong, while ie $_{2}$ (the concord element) is weak (cf. i.a. Cardinaletti and Starke 1999 for general discussion of strong vs weak elements).

(5) The history of negative expressions in various languages makes us witness the following curious fluctuation: the original negative adverb is first weakened [my emphasis - TB], then found insufficient and therefore strengthened, generally through some additional word, and in its turn may be felt as the negative proper and may then in course of time be subject to the same development as the original word.

(Jespersen 1917: 4)

Evidence of $n i e_{1}$ 's strength vis-à-vis nie 2 's weakness comes from asymmetries in:

(a) omissibility: $n i e_{2}$ may be omitted without affecting sense or grammaticality. This occurs quite readily in the spoken language, sometimes clearly for performance-related reasons (e.g. a particularly long negative clause) and it is the rule in headlinese (see Section 2.4.2 below). By contrast, nie $_{1}$ can never be omitted. ${ }^{5}$

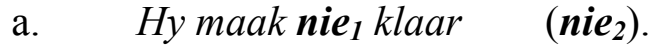
he make not finished POL
'He isn't finishing up.'
b. *Hy maakklaar nie $_{2}$. he make finished POL

(b) modifiability: nie $_{1}$ can be strengthened or weakened via adverbial modification, while the same option is not available to $n_{i} e_{2}$.
a. Jy let glad/ absoluut/miskien/moontlik nie op $_{1}$ nie $_{2}$.
you attend altogether/ absolutely/maybe/ possibly not up POL
'You aren't remotely paying attention.'

\footnotetext{
5 As shown in Biberauer (2008), it is also always nie 2 which undergoes haplology in contexts where two nies would otherwise have surfaced adjacent to one another within a single prosodic phrase.
} 
b. *Jy let nie ${ }_{1}$ op glad/absoluut/miskien/moontlik nie $_{2}$.

(c) substitution by a stronger negative form: ie $_{1}$ can be replaced by an alternative negationelement to produce a stronger negative meaning; the same option is not available to $n_{i} e_{2}$.
a. Ons is nie ryk nie $_{2}$.
us is not rich POL
'We are not rich.'
b. Ons is geensins ryk nie . $_{2}$
us is not-remotely rich $\mathrm{POL}$
'We are not remotely rich.'
c. *Ons is nie 1 ryk geensins.

(d) stressability (here and elsewhere CAPITALS signal focus intonation): ie $_{1}$ can be stressed in order to reinforce the negative meaning it expresses; ${n i e_{2}}_{2}$ cannot.
a. Ekweet $\mathrm{NIE}_{1}$ wat sy bedoel nie 2 . [denial]
I know not what she mean POL
'I DON'T know what she means.'
b. $\quad$ *Ek weet nooit/nie, wat sy bedoel $\mathrm{NIE}_{2}{ }^{6}$
$\neq$ 'I DON'T know what she means.'

The differences between the two nies are summarised in Table 1:

Table 1: Summary comparison of the properties of $n i e_{1}$ and $n i e_{2}$ in Afrikaans

\begin{tabular}{|l|c|c|}
\hline \multicolumn{1}{|c|}{ Property } & $\mathrm{nie}_{1}$ & $\mathrm{nie}_{2}$ \\
\hline 1. Omission $\rightarrow$ ungrammaticality/meaning change & YES & $\mathrm{NO}$ \\
\hline 2. Modifiability & YES & NO \\
\hline 3. Substitution by emphatic negator & YES & NO \\
\hline 4. Stressability & YES & NO \\
\hline
\end{tabular}

\footnotetext{
${ }^{6}$ The only contexts in which nie $_{2}$ may be stressed are metalinguistic, e.g. where a speaker repeats a preceding utterance which lacked $n i e_{2}$ in violation of the prescriptive norm (here $n i e_{2}$ may receive more stress than $n i e_{1}$ as in (i), without any reinforcement of the negation expressed; where $n i e_{I}$ is stressed, emphasis naturally results cf. (9a) above and (ii) below), or where a speaker wishes to emphasise the negative nature of the utterance (here both/all negative elements are likely to be emphasised, as in (iii)):

(i) Hulle sal nie $_{1} \mathrm{kom}$ NIE . they shall not come POL

'They won't be coming.' (correction parallel to He ISN'T coming after He ain 't coming in English)

(ii) Hulle sal $\mathbf{N I E}_{1} \mathrm{kom} \boldsymbol{n i e}_{2}$. they shall not come POL 'They WON'T be coming.' (reinforced negation)

(iii) Hulle sal $\boldsymbol{N I E}_{1}$ kom $\boldsymbol{N I E}_{2}$. they shall not come POL

'They WON'T be coming.' (reinforced negation)
} 
What we see, then, is that $n i e_{1}$ and the position associated with $\mathrm{NEG}_{1}$ can be strengthened in various ways, whereas the same is not possible where $n_{i e}$ is concerned. In JC terms, this is particularly significant as it unambiguously indicates, firstly, that the "real" negation element, i.e. $n i e_{1}$ or $\mathrm{NEG}_{1}$ in (1), is not a weak element, ${ }^{7}$ and that the concord element, i.e. nie $_{2}$ or $\mathrm{NEG}_{2}$ in (1), is weak. Clearly, therefore, phonological considerations cannot have been what triggered the rise of nie $_{2}$. As we will see in Section 2.3.1, discourse-pragmatic considerations may well have played some role, but a rather different consideration appears to have been decisive. For the moment, the key observation is that there is no evidence that $n_{i}{ }_{2}$ in contemporary Afrikaans is developing in the way that $\mathrm{NEG}_{2}$ elements in better studied European languages have: there does not appear to be any move in the direction of JC Stage IV.

Significantly, however, Afrikaans is also not inert in JC terms: as Biberauer (2009) observes, there are two striking developments in modern spoken Afrikaans (MSA) which point to the fact that the negative domain is not in fact entirely stable. ${ }^{8}$ These developments are summarised in the following section.

\subsubsection{Negative developments in modern spoken Afrikaans (MSA)}

MSA exhibits the following negative reinforcement strategies:

(a) expansion of the contexts in which $n i_{2}$ surfaces, and

(b) nie $_{1}$ replacement.

\subsubsection{Expansion of nie $_{2}$ contexts}

In addition to its obligatory clause-final position, $n i_{2}$ may also, in standard Afrikaans, optionally surface in constituent negation structures of the type illustrated in (10-11):

(10) a. Nie $_{1}$ die GELD nie $_{2}$, maar die TYD pla hom. not the money POL but the time worry him 'Not the MONEY, but the TIME worries him.'

b. Moeder Natuur het vir nie minder nie $_{2}$ as drie beskermende Mother Nature have for not less POL than three protective lae gesorg. layers cared 'Mother Nature provided no less than three protective layers.' i.e. negatively focused constituents

(11) A: Wie het my sjokolade gesteel? who have my chocolate stolen 'Who has stolen my chocolate?'

\footnotetext{
${ }^{7}$ There are circumstances under which nie $_{l}$ can be reduced - cf. (i). Crucially, however, nie $_{l}$ reduction never renders it phonologically weaker than ie $_{2}$ (except in the metalinguistic contexts mentioned in the previous footnote):

(i) Hy iss-ie moeg-iel *nie/ *NIE he is- not tired- POL POL POL 'He isn't tired.'

${ }^{8}$ See Section 5 below for discussion of a further instability in the Afrikaans negation system.
} 
B: Niemand nie ; $_{2}$ dis onder jou leesboek!

no-one POL it's under your read.book

'No-one; it's under the book you're reading!', i.e. fragment answers

In the spoken Afrikaans of many speakers, including myself, $n i e_{2}$ may additionally feature in emphatic structures such as that illustrated in (12): ${ }^{9}$
a. Hulle is [nooit $\left(\right.$ nie $\left.\left._{2}\right)\right]$ tevrede nie $_{2}$. they is never POL satisfied POL
'They are NEVER satisfied.'
b. Sy het [nêrens (nie 2$)]$ tuis gevoel nie ${ }_{2}$ she have nowhere POL at.home felt POL 'There was NOWHERE she felt at home.', i.e. She didn't feel at home anywhere.

Biberauer (2009, 2012a) proposes that (12)-type structures signal that MSA is undergoing a "sub-Jespersen's Cycle": non-clausal constituents, which are at Stage I in standard Afrikaans, are moving to Stage II in some spoken varieties, namely those where a reinforcing negator may optionally co-occur with the negative element. As we will see in Section 2.3.2, this development has important consequences for $n_{i} e_{2}$ 's categorial specification.

\subsubsection{2. $\mathrm{Nie}_{1}$-replacement}

As noted in Section 2.2.1 above, nie $_{1}$ can be reinforced by means of lexical substitution (cf. (8b)). Two recently innovated lexical substitutions that are not standardly acceptable, but that are widely used in colloquial Afrikaans involve the negative quantifiers $g$ ' $n$ (>geen - 'no' $)^{10}$ and niks ('nothing'; cf. Biberauer 2009 and Huddlestone 2010 for detailed discussion). ${ }^{11}$ These usages are illustrated in (13-14) below:

A: Wat 'n goeie uitslag!
what a good result
'What a good result!'

B: Dis $g^{\prime} \boldsymbol{n} / \boldsymbol{G}^{\prime} \boldsymbol{N}$ 'n goeie uitslag (nie 2 ); dis ' $n$ volslae ramp! ${ }^{12}$ it's no no a good result POL it's a total disaster 'It's NOT a good result; it's a total disaster!'

9 As Biberauer (2009) shows, consideration of the properties differentiating $n i e_{1}$ and $n i e_{2}$ makes it clear that the "extra" nie in these structures is $n i e_{2}$. Square brackets in each case indicate that this $n i e_{2}$ must be part of the same prosodic domain as the negative indefinite that it reinforces.

${ }^{10}$ As discussed in Biberauer (2009) and Huddlestone (2010), $g$ ' $n$ can very clearly be shown to be a lexical item distinct from the full-form negative quantifier, geen; it is a grammaticalised version of this element, which survives in full and reduced forms alongside sentential negation-signalling $g$ 'n. In most contexts in which it occurs, it can surface as either a neutrally stressed $\left(g^{\prime} n\right)$ or specially focused $\left(G^{\prime} N\right)$ form. Where $g^{\prime} n$ modifies $n i k s$ as in (15b), it necessarily carries neutral intonation, however; the first component of (15a) and that of (15b) therefore form an instructive minimal pair. For a context where $g$ ' $n$ is obligatorily focused, see (17).

${ }^{11}$ See Bayer (2009) for discussion of the use of 'nothing' as a reinforcing negation element and also for further references.

${ }^{12} \mathrm{Nie}_{2}$ is most naturally omitted in structures of this type; cf. also (15a) and particularly (15b), where nativespeakers are notably loathe to accept final $n i e_{2}$. By contrast, inclusion of $n i e_{2}$ is much more natural with niks (cf. (16)). This phenomenon merits more detailed investigation, which we must leave to future work. 
B': Dis $\boldsymbol{g}^{\prime} \boldsymbol{n} / \boldsymbol{G}^{\prime} \boldsymbol{N}$ 'n goeie uitslag (nie 2 ); dis 'n FANTASTIESE uitslag! it's no no a good result POL it's a FANTASTIC result 'It's NOT a good result; it's a FANTASTIC result!'

(14) A: Wat het gebeur? what have happened 'What happened?'

B: Jan is niks tevrede met sy spelers nie ${ }_{2}$ en het die spanfisio John is nothing satisfied with his players POL and have the team.physio afgedank. fired 'John isn't at all happy with his players and he's fired the team physio.'

As (13) shows, $g$ 'n substitutes for $n i_{1}$ in what we can broadly think of as presuppositional or, more accurately, "activated" negation contexts, notably denials (cf. i.a. Dryer 1996 on 'activation', and also Schwenter 2002, 2005 and Larrivée 2010 for more fine-grained discussion of this notion in relation to negative structures). This is possible not only with regular, proposition-oriented denials (cf. the B response in (13)), but also, as shown by the B' response, with metalinguistically-oriented denials. Niks, by contrast, is not restricted by discourse considerations of this type, being possible in "activated" contexts, but crucially also, as (14) illustrates, in out-of-the-blue contexts. Importantly, it also differs from $g$ 'n in that it expresses what Horn (1989) designates contrary (scalar) negation, whereas g'n expresses contradictory (polar) negation. Evidently, then, the two substitution possibilities have clearly defined domains.

Their distinct functions are also very evident in cases where they co-occur, as the following examples show ([ ] indicate elements associated with the same prosodic phrase):

a. Sy is $\mathbf{g}^{\prime} \boldsymbol{n} / \boldsymbol{G}^{\prime} \boldsymbol{N}$ [niks tevrede] nie $\boldsymbol{n}_{2} ;$ sy is doodgelukkig met die lewe. she is no no nothing satisfied POL she is dead-happy with the life 'She's NOT thoroughly dissatisfied; she's dead happy with her life.' [i.e. double negation: she's VERY content]

b. Sy is [g'n niks tevrede] nie , $_{2}$ orals is daar fout. she is no nothing satisfied POL everywhere is there fault 'She absolutely isn't happy at all; she's finding fault with everything.'

In (15a), $g$ 'n and niks function independently to express both contradictory and scalar negation in the context of a denial, whereas in (15b), where these elements form part of a single constituent and $g$ 'n modifies niks, we have an emphatic instance of the type of negation (scalar, with activation status not mattering) reserved for niks. The same effects emerge when $g$ 'n and niks and combinations of these two elements are reinforced by the strategy discussed in the previous section, namely "extra" ie $_{2}$ reinforcement. This is shown in (16-17):
a. Dit is $\mathbf{g}^{\prime} \boldsymbol{n} / \boldsymbol{G}^{\prime} \boldsymbol{N}$ nie $_{2}$ so moeilik nie $_{2}$ !
it is no no POL so difficult POL
'It's NOT so difficult at all!' 
b. Sy is niks nie $_{2}$ tevrede nie . $_{\text {. }}$

she is nothing POL satisfied POL

'She isn't REMOTELY satisfied.'

a. Dit is $\boldsymbol{G}^{\prime} \boldsymbol{N}$ [niks nie $_{2}$ ] so moeilik nie $_{2}$.

it is NO nothing POL so difficult POL

'It's NOT not so difficult.', i.e. it IS difficult

b. Dit is [g'n niks $\left.\boldsymbol{n i e}_{2}\right]$ so moeilik nie $_{2 .}$

it is no nothing POL so difficult POL

'It's NOT so difficult.'

What we see, then, is that there are a variety of substitution mechanisms via which the negation neutrally expressed by nie $_{1}$ may be strengthened.

\subsubsection{Conclusion}

What this section has shown is that modern-day colloquial Afrikaans features a range of negative reinforcement strategies, some of which draw on the $\mathrm{NEG}_{2}$ element (nie 2 ). Strikingly, however, none of these developments entail weakening of the still-strong $\mathrm{NEG}_{1}$ element $\left(n i e_{1}\right)$ or the rise of structures featuring only nie 2 . There is, thus, no evidence at all of modern Afrikaans proceeding to a following stage of JC within the clausal domain. This state of affairs could simply reflect the fact that Afrikaans has opted for stability in the JC context, rendering it an uninteresting language from the perspective of researchers interested in understanding the factors contributing to cyclic developments (see i.a. van Gelderen 2009, 2011, and van der Auwera 2010 for discussion). Our proposal, however, is that this is not the case and that Afrikaans in fact points to relevant properties of negation systems that have not previously been considered in researchers' attempts to understand JC. The basis for this proposal is the observation that modern-day colloquial Afrikaans cannot be viewed as entirely inert in the JC context: while it certainly is not progressing to Stage IV in the clausal domain, changes in the distribution of $n^{2} e_{2}$ in sub-clausal domains such as those discussed in Section 2.2.2.1 in particular (but see also (16-17)) suggest that a sub-clausal or "internal" cycle may be underway, with non-clausal constituents moving from Stage I (no reinforcement) to Stage II (optional doubling). Additionally, we also observe what might be thought of as a "short cycle" (cf. van der Auwera and Neuckermans 2004) in terms of which $n_{i} e_{1}$ is instantaneously replaced by a different lexical item. We will return to this latter development - which could, of course, also be viewed in non-cyclic terms simply as a direct lexical reinforcement strategy - and, in particular, the elements it involves in Section 3 below. Our immediate concern in the following section will be with the question of why nie ${ }_{2}$ appears to have been "diverted" from the development schematised in (4) above (Stage III-IV/V), instead extending its domain in such as way that it is effectively becoming a generalised concord element, i.e. one which isn't limited to the domain of sentential negation.

\subsection{Understanding the peculiar trajectory of nie ${ }_{2}$ in MSA}

Biberauer (2009, 2012a) proposes that nie,'s failure to progress within JC as standardly conceived is rooted in its origins. If we consider the etymological origins of the $\mathrm{NEG}_{2}$ elements in familiar Western European languages, we observe that French drew on a 
minimiser (pas - 'step'), while English, German and Dutch all utilised a lexical item meaning 'nothing'. Afrikaans, by contrast, harnessed an element whose origins have been disputed, but most plausibly entailed a discourse marker of some kind. Let us consider this question briefly (cf. den Besten 1986 and Roberge 2000 for more detailed discussion).

\subsubsection{The origins of nie $_{2}$}

Undoubtedly key to understanding the origins of $n_{i e}$ is the impression that arises from extant sources that clause-final nie was a late development: while Dutch was introduced at the Cape of Good Hope in 1652, final nie is first mentioned in the report of an early $19^{\text {th }}$ century field cornet, who attributes it to a Khoi speaker (cf. Roberge 2000: 135ff and Deumert 2002, 2004):

(18) ... toen kwam hij zo ewen parmantig en de kraal en hij het een leeven met mijn broeder hij zegt hij hem zal weis wat hij niet weet niet. Toen heef ik hem gezeit ... dat hy moet ophou om met ou gezwint twist te makt dat het niet zal goet gaat. ... hij maar altijt staat en vloek en schel mijn en zeg dat ik hem van aavon niet moet los maak niet

Then he [the Hottentot] came so impudently into the kraal and he has a life (disagreement) with my brother; he says that he will show him what he does not know. Then I [Foecee] said to him ... that he must immediately stop making trouble with the old fellow, that it will not go well for him ... but he [the Hottentot] stood there the whole time swearing and cursing at me and said that I must not let him loose tonight.

(C.J. Foecee 1810; Cape Town Language Archive 206)

Systematic occurrence of nie $_{2}$ in written texts is, however, only attested from the end of the $19^{\text {th }}$ century, during the era of the so-called Taalbewegings ('Language Movements') when many of Dutch extraction became concerned to establish the Cape Dutch variety as a linguistic entity distinct from Dutch, with both low and high functions (cf. Ponelis 1993 and Deumert 2002 for overview discussion). What is striking is that the use of $n i e_{2}$ was anything but categorical, even at the time of Afrikaans's standardisation in 1925, with its distinctiveness in relation to Dutch - the language from which proponents of Afrikaans sought to distinguish it - proving decisive in its selection as a normative feature (cf. again Deumert 2002 for discussion). ${ }^{13}$ For researchers concerned with nie 2 's origins, a key question, then, is how its late introduction is to be understood.

As Roberge (2000) observes, four types of answer have been proposed, namely:

(a) the Afro-Malayo-Portuguese hypothesis, in terms of which Angolan and Malay slaves brought to the Cape by Portuguese sailors were responsible for the introduction of nie $_{2}$. Valkhoff (1966: 13) cites the availability of structures of the type illustrated in (19) in the Portuguese of $17^{\text {th }}$ century sailors (cf. also discussion of Brazilian Portuguese in Section 3):

\footnotetext{
${ }^{13}$ See Section 5 for the proposal that this language-planning decision may in fact have given rise to a system which cannot be acquired on the basis of primary linguistic input alone.
} 
Why this feature would have taken so long to emerge in the attested Cape Dutch texts and commentaries, however, remains a mystery on this proposal.

(b) the Khoekhoe hypothesis, in terms of which the final negator found in modern Khoekhoe varieties - cf. (20) - is taken to be the source for $n i e_{2}$. This hypothesis was particularly strongly endorsed in the work of Hans den Besten:

$$
\begin{aligned}
& \text { a. Hi-si //xu-//ã-b ko-se //'ai tama. } \\
& \text { next summer until spoil } \mathrm{NEG}_{\mathrm{IND}} \\
& \text { 'It won't spoil till next summer.' } \\
& \text { b. } \quad \text { ' } \tilde{u} \text { - !num-ts ka na te? } \\
& \text { beard- get- } 2 \mathrm{SG} \text { MOD ASP NEG } \\
& \text { 'Won't you want to have a beard?' }
\end{aligned}
$$

In terms of this contact explanation, the attribution of the earliest uses of ie $_{2}$ could potentially be accounted for, although it is worth noting in this connection that $n i e_{2}$ in the variety of Afrikaans which is most substantially influenced by Khoekhoe - so-called "Orange River Afrikaans" (cf. Ponelis 1993) - is an optional element. Furthermore, it is also worth noting that the final negator in Khoekhoe is the "real" negator $\left(\mathrm{NEG}_{1}\right)$, whereas this is not the case in Afrikaans (barring the haplology cases mentioned in note 4).

(c) the $17^{\text {th }}$ century NC-retaining Dutch dialects hypothesis, which has often highlighted the double-nie-containing Aarschots variety in particular. Den Besten (1986), however, clearly shows that the Aarschots system crucially differs from the Afrikaans one in that its "extra" nie surfaces clause-internally rather than clause-finally. Viewed from the perspective of modern Afrikaans, Aarschots effectively has only the non-clausal doubling found in modern colloquial Afrikaans, and not the clause-final doubling associated with the standard language (cf. also Aelbrecht 2008a,b for discussion of Asse Dutch and van der Auwera and Neuckermans 2004 and van der Auwera et al. 2006 for further discussion of Dutch varieties permitting clause-internal doubling). The following examples illustrate the Aarschots pattern:

a. $\quad$ Hij heeft geen woord (niet) gesproken.

[Aarschots] he has no word NEG spoken 'He has not said a thing.'

(Pauwels 1958: 441)

b. ' $k$ heb niemand (niet) gezien.

I have no-one NEG seen

'I have seen no-one at all.'

(d) the spoken Dutch emphatic tag/resumptive hypothesis, in terms of which nie $_{2}$ originated as a discourse marker of the type illustrated in (22) (cf. Roberge 2000 for details of this proposal): 
a.

$$
\begin{aligned}
& \text { Het kan niet waar zijn, nee! } \\
& \text { it can not true be no } \\
& \text { 'It can't be true, no!' }
\end{aligned}
$$

b. Jij komt niet mee, ne?

you come not with hey

'You aren't coming, hey/right?'

The specifics of this proposal remain to be worked out - and here one cannot help but wonder what new insights Hans would have presented in June 2010, had he been present at the postdefense colloquium mentioned in Section 1 - but two clear merits are (a) the fact that it can account for nie,'s late attestation - tag negators/resumptives are spoken-language elements par excellence - and (b) also that a discourse-related origin would seem to bring Afrikaans (further) into line with other so-called "Bipartite Negation with Final Negator/BNF" languages (cf. Bell 2004), i.e. those in which the concord element is clause-final as opposed to just postverbal. As far as we have been able to ascertain, these elements derive either from the anaphoric negator (cf. many of the Romania Nova and Bantu varieties discussed by Lipski 2001, and deVos and van der Auwera 2013, respectively) or from some kind of discourse particle (cf. Hagemeijer's 2007 discussion of Santomé). We discuss these sources and BNF languages in more detail in Section 4 below.

In the context of the present article, it is sufficient to observe that the source of $n i e_{2}$ clearly was not either a minimiser (like French pas) or a quantifier (like the English, German and Dutch negators). If source considerations are as significant as researchers such as Zanuttini (1997), Poletto (2008a) and Biberauer (2009, 2012a) suggest, then, we would not expect Afrikaans to behave like any of these languages (contrary to what was sometimes professed by advocates of the Taalbewegings). ${ }^{14}$ In the following section, we will see that there additionally appear to be formal reasons why this should be so.

\subsubsection{The formal properties of nie $_{2}$ vis-à-vis other reinforcers}

In generative diachronic terms, the source of a given element matters in the sense that this will determine the initial structural position associated with the element prior to its having become grammaticalised (cf. i.a. Roberts and Roussou 2003, van Gelderen 2004, Roberts 2007, 2010). Both minimisers like pas and forms meaning 'nothing' would, for example, initially have been merged in structurally low positions, e.g. within the VP. Once they had been incorporated into the negation system - where necessary, being ascribed specifically negative features which they had previously lacked - they might be expected to be analysed as negative elements, which, by hypothesis, cannot be merged as low as the VP (cf. Zeijlstra 2004 for discussion). Nevertheless, the work of Zanuttini (1997) and Poletto (2008a) suggests that the etymological origins of a given negator still play a role in determining its post-

\footnotetext{
${ }^{14}$ S.J. du Toit (1876/1897) in his Eerste beginsels van die Afrikaanse taal ('First principles of the Afrikaans language'), for example, presented the Afrikaans negation system, which he wished to promote as standard, as follows: Nes in Frans het ons een dubbele ontkenning in ons tweemaal 'nie', i.e. 'Just like in French, we have a double negation with our double use of nie'.
} 
grammaticalisation canonical structural position. ${ }^{15}$ Combining the insights of their seminal work, ${ }^{16}$ we get the hierarchy of lower and higher negation positions schematised in (23), which needs to be understood in the context of the more elaborated sub-portion of the Cinquean hierarchy given in $(24):^{17}$

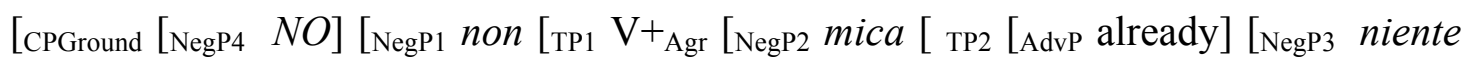
[Asp perf. $\mathrm{V}_{\text {past.part }}$ [Aspgen/progr [AdvP always] ]]]]]]]

[once $\mathrm{T}\left(\right.$ Past) [then $\mathrm{T}\left(\right.$ Future) [perhaps Mood $_{\text {irrealis }}$ [necessarily Mod $_{\text {necessity }}$ [possibly $\operatorname{Mod}_{\text {possibility }}$ [usually Asp habitual [again Asp $_{\text {repetitive(I) }}$ [often Asp frequentative(I) $_{\text {intentionally }}$ Mod $_{\text {volitional [quickly Asp }}$ celerative(I) [already T(Anterior) [no longer Asp terminative [still Asp $p_{\text {continuative [always Aspect }}$ perfect [just Asp retrospective [soon Asp proximative [briefly Asp $_{\text {durative }}$ [characteristically Asp generic/progressive [almost Asp prospective [completely

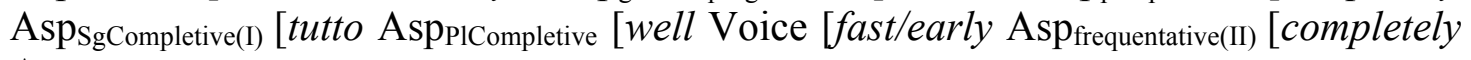
AspsgCompletive(II) $\ldots$

(Cinque 1999: 106)

Let us firstly compare (23) and (24). What is crucial here is that both of the elements that feature as reinforcers in the well-known European studies of JC - niente ('nothing') and mica ('crumb', i.e. minimiser-type elements) - are negation elements, which, following their grammaticalisation as such, occupy low clausal positions: niente is located just above the $\mathrm{Asp}_{\text {perfect }}$ and mica just above $\mathrm{TP}_{2}$, which hosts anterior adverbials like already and is thus, in effect, a further Aspect-projection, located well within Cinque's (1999) Aspectual 'field' (see i.a. Tenny 2000, and Biberauer and Roberts 2015 for discussion of the notion 'field' or 'zone' in clausal structure). Both of these negators are thus plausibly located within the lexical vPdomain (cf. the 'first-phase' in Ramchand's 2008 system). That is, their upward reanalysis upon becoming negative elements has kept them within the lowest of the three core clausal domains typically identified within modern generative syntax (cf. i.a. Grohmann 2003). These are illustrated in (25):

15 Poletto (2008a: 64) states this explicitly as follows: "each negative marker singled out by Zanuttini corresponds to an 'etymological type' in the sense that all elements found in a given position have developed from homogeneous classes".

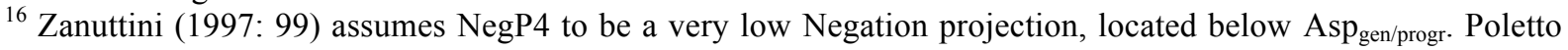
(2008a,b), however, argues that this NegP, which is always occupied by negators which have their origin in the anaphoric sentential negation element, no, is located in CFoc, the Focus-head within Rizzi's articulated CP (cf. Rizzi 1997). As the final negation elements we are concerned with here closely resemble those discussed in Poletto (2008a,b), we follow this author in locating NegP4 within the CP-domain (i.e. high). We leave aside the intriguing possibility that Zanuttini's apparently low Neg, also realised by no in Milanese and Pavese, may be the reflex of these varieties having an acategorial no, which can therefore combine directly with a range of clausal and sub-clausal XPs (see following main text and also Biberauer forthcoming for discussion of acategorial elements).

${ }^{17}$ It is worth noting that Cinque's (1999) detailed cartographic analysis of the clausal domain does not ascribe a consistent position to negative elements as it is clear that the position of these elements is, to a larger extent than for other adverbs, determined by scopal considerations. Furthermore, it is clear that languages differ as to the default position associated with the overtly realised sentential negation marker, Germanic negators, for example, surfacing in a lower position (somewhere within the vP domain; cf. i.a. Haegeman 1995; van Kemenade 2000, 2011; Wallage 2005; Ingham 2007; Breitbarth 2009; Haeberli 2011) than their Romance counterparts (somewhere within the TP domain; cf. i.a. Zanuttini 1997; Roberts and Roussou 2003; Poletto 2008a,b), and the latter, in turn, surfacing lower than the default negator in Celtic (somewhere in the CPdomain; cf. Willis 2013b). See Willis et al. (2013) for detailed discussion of negation systems in these three language families, and also in Arabic, which exhibits further variation. 


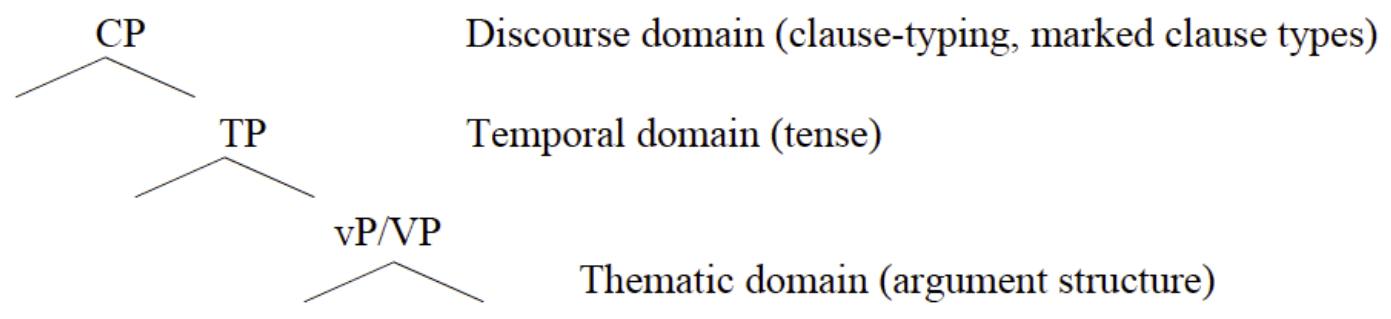

Strikingly, one of the lexical substitutions that we see in MSA derives from this domain too: niks ('nothing') would also have originated as a potential object within VP, subsequently, following extension to other contexts, being reanalysed as a low vP adverbial parallel to niente in Zanuttini's hierarchy (cf. Biberauer 2008 for independent argumentation that ie $_{1}$ is a low vP adverb, and Bayer 2009 on the process via which 'nothing'-elements develop into negatives). $G$ 'n, meanwhile, derives from the negative existential quantifier, geen ('no'), which we would therefore expect to be associated with the domain of existential closure in the first instance. In Diesing's (1992) terms, this is VP. ${ }^{18}$ If grammaticalisation once again involves upwards reanalysis, as was the case with the Western European reinforcers deriving from minimisers and 'nothing'-elements, the fact that both niks and $g$ 'n are able to substitute for $n i e_{1}$ becomes readily explicable: Biberauer $(2008,2009)$ argues that $n i e_{1}$ resembles West Germanic sentential negation markers more generally in being merged low within the clausal projection - within vP to be more precise (cf. also note 17); as such, we can understand why elements associated with nominals that must remain low within the clausal domain may be harnessed to strengthen Afrikaans's sentential negation marker (as hinted in note 18, a fully articulated theory of "cross-domain" grammaticalisation remains to be worked out, however).

Importantly, the above perspective on the negative developments taking place in contemporary Afrikaans entails that the language $i s$, despite superficial appearances to the contrary, undergoing formal changes of a similar type to what occurred in better studied Western European languages. Specifically, low elements are being reanalysed as higher, more

${ }^{18}$ Geen is, of course, a nominal modifier, which we would expect to be merged within the nominal phrase. Consider Poletto's (2008a) proposal that sentential negation markers can be thought of as originating from different positions within nominal structure, as depicted in (i):

(i) $\quad[\mathrm{NEGP}[$ Focus/OperatorP $N O[$ ScalarP non $[\mathrm{MinP}$ mica $[\mathrm{QP}$ niente $[$ ExistentialP $]]$

(Poletto 2008a: 67)

In the context of (i), either of QP or MinP seem like plausible Merge positions for ungrammaticalised geen meaning 'no'. Once it has grammaticalised into a negation marker, it would be expected to be merged higher within the nominal structure, plausibly in ScalarP (see, for example, Israel's 1996, 1997, 2001 work on 'no' as the absolute endpoint of the minimal end of the quantity scale), and also in Focus/OperatorP; these two options may correspond to the unstressed $g^{\prime} n$ vs stressed $G^{\prime} N$ options discussed in Section 2.2.2.2. Interestingly, (i) also suggests that the niente-element in modern spoken Afrikaans (MSA) - niks - has a lower origin within the nominal phrase than $g^{\prime} n$. This, then, corresponds to the lower scope of the negation it expresses compared to $g^{\prime} n$ : recall from Section 2.2.2.2 that niks marks contrary (scalar) negation, whereas $g$ ' $n$ expresses contradictory (polar) negation. In addition to the principal structural-height claims made in this article, then, it seems that there may be further structural-height factors that determine the diachronic development of negation markers and the functions they perform within a system (see also Poletto 2008a for discussion of how nominal and clausal structure may interact in this regard). We leave this intriguing and, to date, largely undiscussed aspect of the grammaticalisation process to future research. 
grammaticalised negative elements, thereby increasing the stock of negation-related functional elements in the language. Crucially, however, the Western European developments led to the introduction of a new type of functional negation element within the vP-domain (the original negator, ne, was clearly T- or possibly even C-related; see again note 17), whereas the Afrikaans developments have led to the introduction of further vP-level negation elements, which may not co-occur with the existing sentential negation marker in vP. Recent research (cf. once again Poletto 2008a,b; Mosegaard Hansen 2009; Larrivée 2010; and Mosegaard Hansen and Visconti 2014) seems to suggest a further parallel between the innovated Afrikaans forms and elements which double an existing negator, namely that both appear to reinforce particular sub-types of negation rather than serving a general reinforcing function in the negative domain. We return to this matter in Section 3 below.

While colloquial Afrikaans can therefore be said to be undergoing reinforcement developments not dissimilar to what took place in languages which have undergone JC, it is nevertheless unambiguously the case that the status of $n i e_{2}$ in the clausal domain remains unchanged: it serves as a concord marker and shows no signs of taking over any of nie $e_{1}$ 's functions. Biberauer $(2009,2012 \mathrm{a})$ suggests that the key difference between $n_{i e}$ and the $\mathrm{NEG}_{2}$ elements which have subsequently established themselves as "real" negators is structural "height": while the latter are all elements drawn from the vP-domain, nie $_{2}$ seems to have derived from a discourse element of some type, i.e. from the CP-domain, or, even more plausibly given the addressee-oriented nature of the putative source constructions (see again (22) above), from a fourth, higher clausal domain (see below). Biberauer (2008, 2009) discusses various synchronic indicators of nie 2 's structural height, of which we mention only one here, namely the fact that $n_{2} e_{2}$ is systematically omitted in headlinese. The examples, featuring, respectively, a particle verb (26a) and a main-clause interrogative (26b) illustrate:

a. Maleisie: 13 lyke spoel op strand uit

Malaysia: 13 bodies wash on beach up

'Malaysia: 13 bodies wash up on the beach' (Beeld newspaper, 2016-01-26)

b. Ken jy dié parke?

know you these parks

'Do you know these parks?'

(Weg magazine, 2016-01-26)

c. Wat gebeur agter 'n teater se gordyn?

what happen behind a theatre POSS curtain

'What happens behind a theatre curtain?'

(Netwerk 24 online news, 2016-01-26)

On the assumption that headlines are instantiations of natural-language grammar, the outputs of a dedicated grammar that differs in systematic ways from the 'source' grammar (cf. i.a. Stowell 1991, Vinet 1993, Paesani 2006, Paul 2007, and Weir 2009), it seems natural to analyse the above structures as outputs of Afrikaans's Verb Second (V2) grammar. Since the finite verb is usually thought to move to C in V2 languages (cf. i.a. den Besten 1977/1983, Schwartz and Vikner 1996, Westergaard 2009, and Holmberg 2015 for discussion), the structures in (26) must all be full CPs. Significantly, nie 2 is conventionally omitted in headlinese - a further reflex of its omissibility (see Section 2.2.1 above). As examples like those in (27) are V2, this points to a structural position above CP for $n i_{2}$ : 
a. Fietsryers en stappers nie I $_{1}$ gestuit cyclists and walkers not thwarted 'Cyclists and walkers not thwarted/put off'

(Die Burger newspaper, 2016-01-26)

b. Hy's nie 1 'kwaadwillig rassisties'

he's not maliciously racist

'He's not maliciously racist'

(Die Son tabloid, 2016-01-26)

We will not concern ourselves here with the precise identity of the structural position occupied by $n i e_{2}$. It does seem worth highlighting, though, that the Afrikaans headlinese facts point to the existence of a clausal domain above $\mathrm{CP}$, an idea which has been gaining momentum in generative circles in recent years (cf. i.a. Tenny 2000, Speas and Tenny 2003, Sigurðsson 2004, Giorgi 2010, Haegeman and Hill 2013, Lam 2014, and Wiltschko 2015). The core idea here is that the clausal domain dominating CP serves as a specifically SpeakerHearer-oriented zone, which grounds the proposition expressed by the root clause in relation to these key discourse participants. (28) gives a schematic representation of the kind of structure being assumed:

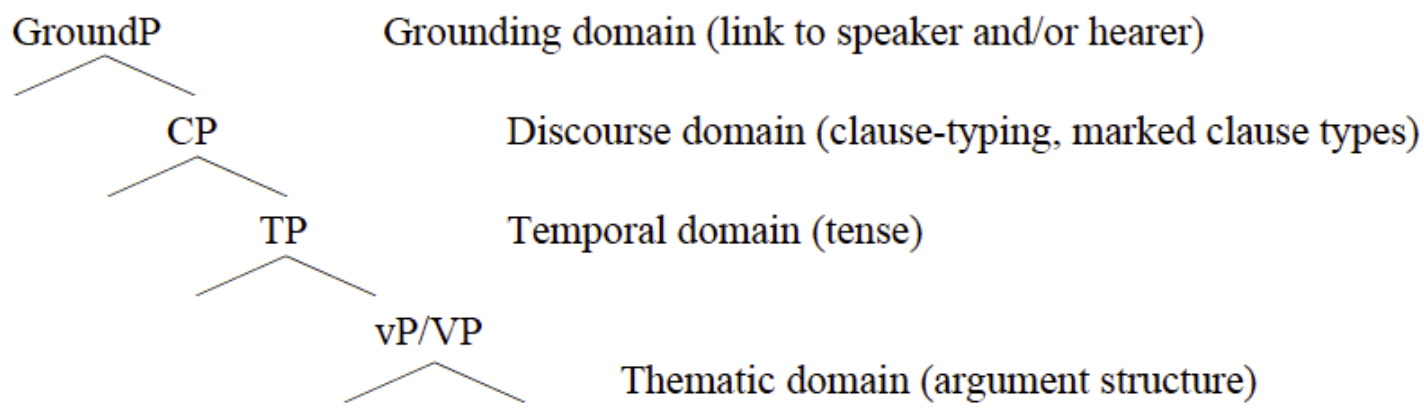

In terms of Roberge's (2000) proposal that nie $_{2}$ originated as a resumptive tag-element that speakers employed to reinforce the negative nature of the proposition expressed, or the prohibitive nature of the speech act intended ${ }^{19}$, and so on, it is very natural to think of $n i e_{2}$ as an element located within the domain labelled as GroundP above.

Taking into account nie,s negation-sensitivity and also Laka's $(1990,1994)$ proposals regarding the potential loci of positive and negative polarity-heads in clausal structure ${ }^{20}$, Biberauer $(2008$,

\footnotetext{
${ }^{19}$ Wiltschko (2015) in fact proposes an articulated GroundP structure containing sub-components dedicated to (i) the Speaker's attitude to the proposition expressed by CP (relevant to resumptive-tag uses of nie ${ }_{2}$ 's source element), (ii) the Addressee's attitude to that proposition (not relevant to these uses), and (iii) what the Speaker wants the Addressee to do (again relevant, as this relates to the speech-act modification use of the resumptive tag mentioned in the main text). (i) is assumed to be $\mathrm{CP}$-adjacent, with (ii) dominating it, and (iii) closing off the structure.

${ }^{20}$ Laka $(1990,1994)$ proposes that the location of PolP - "SigmaP/ $/ \mathrm{P}$ " in her terms - is subject to parametric variation, being associated with what we have here been calling "TP" in some languages and "CP" in others. It may also be the case that there is not a single location within the CP- and TP-domains "reserved" for PolP, i.e. that this projection mirrors negation in not having a fixed hierarchical position (cf. note 17). This idea is further pursued in the main text, where the proposal is that Pol may in fact represent a "shell" which can be
} 
2009, 2012a) follows Oosthuizen (1998) in proposing that the very high left-peripheral position occupied by nie $_{2}$ is the head of a Polarity Phrase (PolP). This is illustrated in (29):

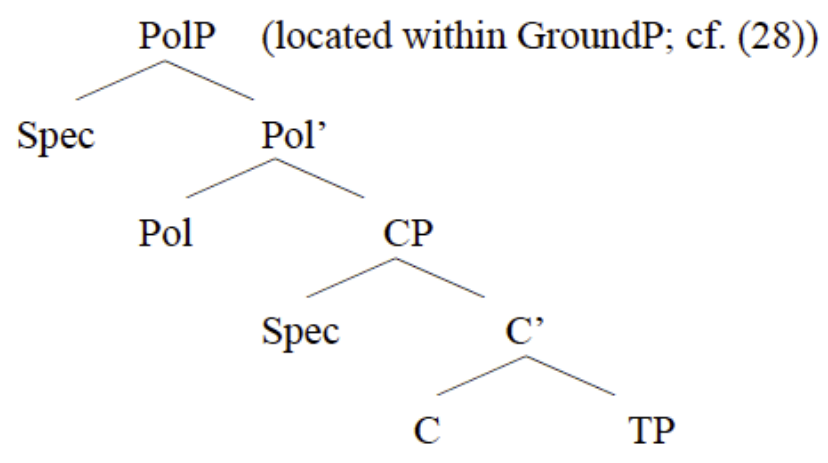

The key point here, as far as we are concerned, is that the very high structural position associated with $n i e_{2}$ contrasts sharply with the much lower position associated with the $\mathrm{NEG}_{2}$ elements in languages which have undergone JC. On the assumption that sentential negation cannot outscope speech-act-related features or, indeed, the operator that encodes the illocutionary force of a given sentence (cf. Han 2001), it is clear that nie $_{2}$ could not develop into a "real" negator $\left(\mathrm{NEG}_{3}\right)$ in the way that pas and similar elements, located lower in the clausal domain, did. In other words, $n_{i} e_{2}$ cannot grammaticalise upwards in the usual way if it is to serve as a sentential negator, as such elements cannot be first-merged so high within the clausal domain. This may be a central consideration in understanding Afrikaans's Stage III stability in the clausal domain. ${ }^{21}$

The increase in the domains in which $n i e_{2}$ may surface (cf. Sections 2.2.2.1 and 2.2.2.2 above) already indicates that this element is extending its domain of use beyond the specifically clausal, which is not what is typically observed in clausal JC developments. Additionally, we also have evidence that $n i e_{2}$ is in fact developing in the opposite direction to that which would be expected in JC terms, i.e. instead of becoming "more negative", it appears to be becoming "less negative". Thus we observe that it is, in the spoken language, able to surface in non-negative contexts such as those illustrated in (30):

activated at the outermost periphery of any independently negatable phrase (just as Focus can; see Biberauer forthcoming for discussion).

In connection with PolP, it is also worth noting that Holmberg (2016) motivates an analysis in terms of which left-peripheral PolP plays a crucial role in (positively and negatively biased) questions. This further underlines the plausibility of associating what Laka $(1990,1994)$ would have viewed as CP-associated PolP with the Speaker-/Hearer-oriented GroundP discussed in the main text. Recent developments in phase theory and also the recasting of Ross's (1970) Performative Hypothesis in modern generative terms (cf. Alcázar and Saltarelli 2014) lead us to expect that there may be a further clause-internal Speaker-/Hearer-oriented left periphery at the vP-edge (cf. Biberauer 2012b, and Biberauer and Roberts in press for discussion and references), thus allowing us to understand English $d o$-support as a member of the family of polarity-related phenomena under discussion here (cf. Biberauer and Roberts 2015 on $d o$-support specifically).

${ }^{21}$ If this is correct, we would expect sentential negation markers in languages which superficially appear to have these located within the CP-domain (e.g. Celtic) to be low CP elements, which are outscoped by speech-act features. 
a. Hy vertrek sonder dat ek agterkom (nie $\left.)_{2}\right)$.

he leave without that I realise POL

'He leaves without me realising it.'

b. Hykon nouliks staan (nie n $_{2}$.

he could barely stand POL

'He could barely stand.'

Oosthuizen (1998) interprets structures such as these as evidence in favour of the idea that $n^{2} e_{2}$ realises a Pol- rather than a Neg-head. ${ }^{22}$ From a syntactico-semantic perspective, then, it seems correct to view nie $_{2}$ as a bleached element.

This is also true if we consider the likely featural consequences of the fact that $n_{i e}$ may surface in a wider range of phrasal contexts in MSA than what is standardly permitted (cf. again the examples in Section 2.2.2.1 above): whereas $n i_{2}$ may originally have been a purely clausal element - one which we can therefore think of in generative terms as extending the verbal spine (cf. Grimshaw 1991 et seq.) and thus bearing verbal features ([+V]) - it is clear that the featural composition of modern-day nie $_{2}$ cannot include any (inherent) categorial specification. If $n^{2} e_{2}$ were categorially specified as [+V], say, to account for its presence in sentential negation structures, we would not expect it to be compatible with negated nominals or PPs as in $(10 \mathrm{a}, \mathrm{b})$ above: merging $n i e_{2}$ at the left edge of a negated nominal or PP does not render them verbal XPs. $\mathrm{Nie}_{2}$, then, must combine with negated XPs in the manner schematised in (31):

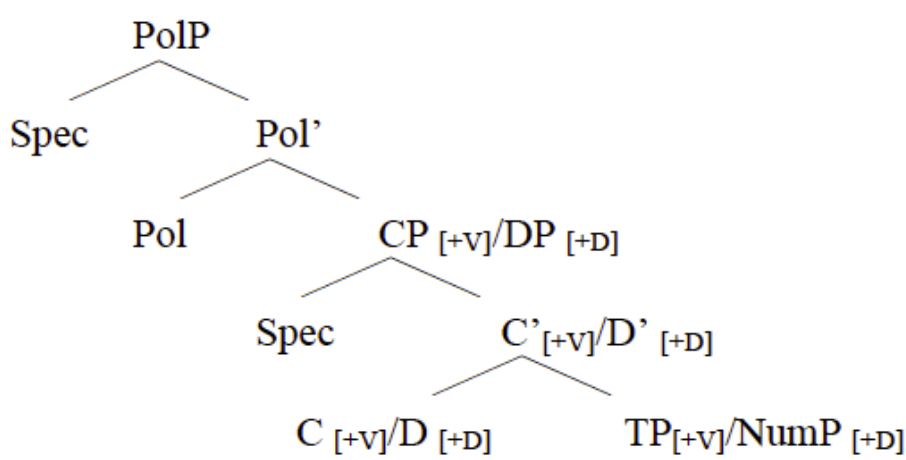

Taking into account the discussion of nie 2 's phonological weakness in Section 2.2.1, we therefore see that $n^{2} e_{2}$ in modern Afrikaans is a syntactically, semantically and phonologically deficient element. Biberauer $(2009,2012 a)$ consequently proposes that it has grammaticalised "beyond the Cycle", with the result that we should not expect it to follow the same diachronic path as $\mathrm{NEG}_{2}$ elements in better studied European languages. More generally, Biberauer (2009, 2012a) takes the Afrikaans facts as the basis for the hypothesis in (32):

(32) Languages which draw on an element from a high structural domain to serve the function of $\mathrm{NEG}_{2}$ will not undergo Stage III to IV/V change.

\footnotetext{
${ }^{22}$ Strikingly, Breitbarth and Haegeman (2010) show that a very similar analysis seems correct for the former $\mathrm{NEG}_{1}$ element, -en, in West Flemish.
} 
In the following sections, we will discuss some systems that initially appear to challenge (32).

\section{Some test cases: Brazilian Portuguese (BP) ${ }^{23}$}

Superficially, BP negative structures share quite a few properties with their Afrikaans counterparts. Consider (33) in this connection:

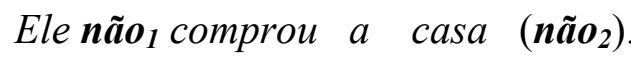

[oral standard Brazilian Portuguese]

he not bought the house NEG

'He has not bought the house.' (Sonia Cyrino, p.c.)

Like Afrikaans, spoken BP negatives may feature two superficially identical negation elements, with the "real" negator surfacing clause-internally and the concord element in clause-final position. There are, however, also some crucial differences, notably that clausefinal $n \tilde{a} o$ is optional and that clause-internal não is a weak element, typically realised in clitic form as num. Clause-final não, by contrast, can never be realised as a clitic (cf. Martins 1997; Cavalcante 2007; Armstrong and Schwenter 2008; Hansen 2009; Teixeira de Sousa 2011, 2013 and Martínez 2013, all contra Fonseca 2004;); at the same time, however, it also cannot be stressed (Sonia Cyrino, Gertjan Postma, p.c.), a fact which will prove important in the context of our discussion.

Importantly for our purposes, northern rural varieties of BP permit an additional negation option that is not available in the spoken standard of the south and that appears to falsify (32). Consider (30) (cf. Schwegler 1991; Martins 1997; Alkmim 1999, 2001, 2002; Camargos 2002; Fonseca 2004; Schwenter 2005; Cavalcante 2007; Hansen 2009; Teixeira de Sousa 2011, 2013):

$$
\begin{aligned}
& \text { Ele comprou a casa não. } \\
& \text { he bought the house NEG } \\
& \text { 'He has not bought the house.' }
\end{aligned}
$$

Here we see that it is possible to negate a northern BP sentence by employing what appears to be just the clause-final negator, or $n \tilde{a} o_{2}$ in (33). If this is indeed the case, (32) clearly cannot be correct, suggesting that structural height may not, after all, be a relevant consideration in determining onward progression beyond Stages II and III. Researchers who have previously suggested that northern BP is in the process of progressing to Stage V include Schwegler (1986, 1991) and Schwenter (2005) and, more speculatively, Lipski (2001). Biberauer and Cyrino (2009a,b), however, dispute this analysis, arguing that (32) is, in fact, supported by the negative developments in BP. The main components of their proposal are summarised in Sections 3.1 and 3.2.

\subsection{A closer look at the northern BP data}

A striking fact about final não-containing structures is that they are systematically interpreted differently from structures featuring only the prescriptively sanctioned medial não. Consider the following examples:

\footnotetext{
${ }^{23}$ As will become clear, the material presented in this section is based on joint work with Sonia Cyrino (see Biberauer and Cyrino 2009a,b).
} 

a. A Maria não 1 /num vaino teatro. the Mary not not.CL go in-the theatre 'Mary is not going to the theatre.'

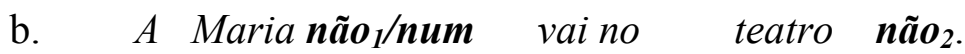 the Mary not not.CL go in-the theatre NEG 'Mary is (emphatically) NOT going to the theatre.'

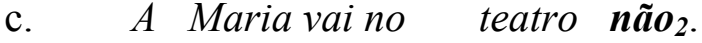 the Mary go in-the theatre NEG 'Mary isn't going to the theatre (as you thought/suggested), no.'

While (35a) can (but need not) be interpreted as a simple declarative, (35b-c) cannot be interpreted in this way. In both of these cases, what is expressed is marked negation: with two $n \tilde{a} o$ s present, the structure is necessarily interpreted as reinforced in a manner parallel to what we see in Afrikaans structures featuring an "extra" nie 2 (cf. Section 2.2.2.1), whereas with just the final não present, the structure is obligatorily interpreted as one which negates a presupposition, e.g. a denial. Strikingly, this latter type is most common in response to yes/no questions (see below), whereas the former type is additionally also acceptable in thetic contexts (e.g. following a question like What is going on?).

Interpretive considerations aside, the final $n \tilde{a} o$ in (35b)- and (35c)-type structures also differ in phonological terms: while independently occurring não may be emphatically stressed, this is not possible with the final $n \tilde{a} o$ that occurs in doubling structures (Sonia Cyrino and Gertjan Postma, p.c.; cf. also Armstrong and Schwenter 2008).

Also striking is the fact that (35b)- and (35c)-type structures exhibit a range of further distributional asymmetries. Thus (35b)-type structures are acceptable in both matrix and embedded clauses, whereas (35c)-type structures are restricted to matrix clauses. This is illustrated in (36):

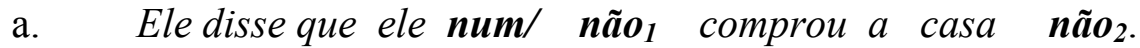

$$
\begin{aligned}
& \text { he said that he not.CL/not bought the house NEG } \\
& \text { 'He said that he hasn't bought a house.' } \\
& \text { b. *Ele disse que ele comprou a casa nãao. }
\end{aligned}
$$

Further, (35b)-type structures are impossible in simple yes/no interrogatives (37a), whereas (35c)-type structures are not (37b); the only constraint on the latter is that they are only licensed in questions entailing a presupposition, a condition which is met in (37b):

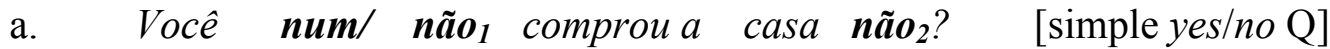

$$
\begin{aligned}
& \text { you not.CL/not bought the house NEG } \\
& \text { 'Haven't you bought the house?' }
\end{aligned}
$$

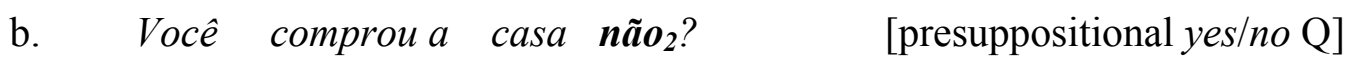

$$
\begin{aligned}
& \text { you buy the house NEG } \\
& \text { 'You DIDN'T buy the house?! (I thought you had!)' }
\end{aligned}
$$


Still further, only (35b)-type structures are available in polite questions involving negation:

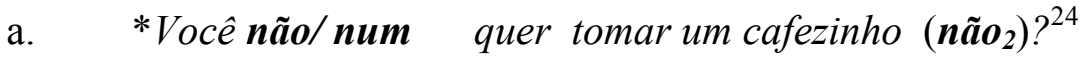
you not not.CL want take a café.DIM NEG
'Wouldn't you like to have some coffee?'
b. *Você quer tomar um cafezinho não

Additionally, (35c)-type structures are incompatible with negative polarity item (NPI) idioms:
Q: $\quad$ J João é rico!
the John is rich
'John is rich!'
A': O que?! ele num/ não 1 tem um tostão furado!
what he not.CL/not has a cent with-a-hole
'What?! He doesn't have a red cent!'
$\mathrm{A}^{\prime \prime}:$ O que? ele num/ $\boldsymbol{n} \tilde{\boldsymbol{a}} \boldsymbol{o}_{1}$ tem um tostão furado $\boldsymbol{n \tilde { \boldsymbol { a } } \boldsymbol { 0 }} \boldsymbol{o}_{2}$ !
what he not.CL/not has a cent with-a-hole NEG
'What?? He doesn't have a red cent!'

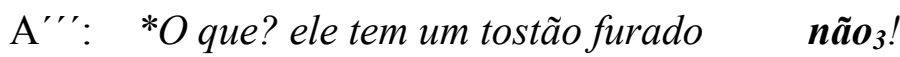
what he has a cent with-a-hole NEG

Significantly, NPI idioms in the (35c)-type structure can only be interpreted literally, their idiomatic meaning necessarily being lost:

(40) Ele tem um tostão furado $\quad \boldsymbol{n} \tilde{a} \boldsymbol{o}_{3}$; ele tem um inteiro!

he has a cent with-a-hole NEG he has one whole

'He doesn't have a red cent; he has a BLUE one.' (i.e. literal meaning)

Again, this is very different to what we see in (35b)-type structures, which, just like (35a)type structures, express idiomatic meanings.

Finally, Hansen (2009) discusses two further differences between (35b)- and (35c)-type structures, namely those relating to their occurrence in topicalisations and relative clauses: in both cases, only (35b)-type structures are permissible. Evidently, then, there are striking discrepancies as regards both the distribution and the meanings associated with the two structures featuring clause-final não.

\subsection{Evaluating the northern BP data in light of JC}

The discrepancies highlighted in the preceding section are mysterious in the context of any account that views (35c)-type structures as innovative counterparts of (35b), as one might if

\footnotetext{
${ }^{24}$ The reason for (37a)'s unacceptability would seem to be that reinforcement of a negative-containing question naturally delivers an "activated" echo/surprise reading, i.e. an interpretation which is systematically associated with (35c)-type structures. In other words, a type of blocking effect appears to be active here.
} 
one adopts a JC perspective on the developments in northern BP: why should the apparent Stage IV/V structures be subject to so many restrictions that do not apply to the apparent Stage II/III structures? Worth noting is that there is no context in which não-doubling is obligatory in these varieties. It therefore cannot be correct to characterise these varieties as former Stage III varieties, which are now in the process of moving on to Stage IV. ${ }^{25}$ Taking these considerations into account, Biberauer and Cyrino $(2009 \mathrm{a}, \mathrm{b})$ propose that the clausefinal nãos in northern BP must in fact be analysed as distinct lexical elements which have developed independently of one another, possibly from distinct sources.

As regards the synchronic analysis of these forms, the proposal is that final não in (35b)-type structures - henceforth $n \tilde{a} o_{2}-$ is a genuine concord element, lexicalising a Pol-head similar to Afrikaans nie $_{2}$, though possibly located in a slightly lower position (cf. note 20 and see Biberauer and Cyrino 2009a,b for detailed discussion). Final não in (35c)-type structures henceforth $n \tilde{a} o_{3}$ - is not a concord element; instead, this is the anaphoric negation element which is generally employed to give negative answers to yes/no questions, but which is harnessed in (35c)-type structures to act as a specialised reinforcer which exhibits behaviour not dissimilar to that of Afrikaans $g$ ' $n$. Recall from Section 2.2.2.2 that $g$ ' $n$ is restricted to activated contexts, such as denials. As we saw in the previous sections, northern BP $n \tilde{a} o_{3}$ is similar in that it may also only be used to express presuppositional negation. Furthermore, $n \tilde{a} o_{3}$ and $g$ 'n exhibit the same behaviour in relation to idioms. Consider (41) below:

a.

$$
\begin{aligned}
& \text { Ek het } \boldsymbol{G}^{\prime} \boldsymbol{N} \text { ' } n \text { bloue duit nie } \boldsymbol{e}_{2} \text { ek het 'n GROENE! } \\
& \text { I have no a blue ducat NEG I have a green } \\
& \text { 'I DON'T have a red cent; I have a GREEN one!' }
\end{aligned}
$$

b. Ek het G'N nie ' $^{\prime}$ bloue duit nie 2 ; ek het HORDES geld!

I have no not a blue ducat NEG; I have heaps money

'I DON'T not have a red cent; I have HEAPS of money!'

As (41a) shows, $g$ ' $n$ - which, crucially, must be focused in this case (see notes 10 and 18) cannot license NPI idioms; as is the case with northern BP não $o_{3}$, the only available interpretation is a literal one. As soon as Afrikaans's "real" negator, nie $e_{1}$, is included, however, the idiomatic meaning returns (41b). The same is true in northern BP, as (39A") above shows.

Biberauer and Cyrino (op.cit.) ascribe não,'s behaviour to the fact that it, unlike não $o_{2}$, is not fully integrated with the clausal spine: while $n \tilde{a} o_{2}$ is plausibly a Pol-head, projecting as part of the verbal spine which forms the backbone of the clause (cf. Laka 1990, 1994 and (29) above), não $o_{3}$, like anaphoric negators more generally, is effectively an adjunct. As such, it cannot license NPIs associated with the main clausal spine, regardless of whether these are arguments, predicates or other adjuncts. We see the same effect in English:

$$
\begin{aligned}
& \text { a. *No, I drink anything/a drop } \\
& \text { b. No, I don't drink anything/a drop }
\end{aligned}
$$

\footnotetext{
${ }^{25}$ It is worth noting that the fact that Stage III doubling has not become the neutral pattern in northern BP does not itself preclude the possibility that Stage IV might become established as such, as it is not clear that the stages of JC should be viewed as necessary milestones which systems progressing through JC in fact have to stop off at in strict sequence.
} 
In Afrikaans, the fact that $g^{\prime} n$ is obligatorily focused in structures of this type (cf. (41)) brings about the creation of a "sealed off" phrase, which therefore also does not interact with the main clausal spine in the usual manner (cf. Biberauer and Cyrino 2009a,b; Biberauer and Zeijlstra 2012a,b; and Biberauer and Roberts 2011 for more detailed discussion of this "sealing off" effect under focus and further references).

Further evidence in favour of the proposal that the final não in (35b)-type doubling structures should not, as a JC-oriented perspective might suggest, be viewed as the source of final não in (35c)-type structures comes from closer consideration of the properties of oral standard BP and northern BP. Given its distributional properties, the most plausible source for não $o_{3}$ in northern BP would appear to be a negative short-answer structure which does not exist in other varieties. Whereas short answers to narrow-scope yes/no questions are identical in these varieties - the anaphoric negator provides a negative answer, while the copula élfoi ('is, was') signals a positive answer - short answers with wide scope differ in a crucial way: positive answers are again the same across varieties, taking the form of a repeated verb which may additionally be accompanied by the particle, sim ('indeed'; cf. (43)); for negative answers, however, northern BP, unlike oral standard BP, has the option of employing the anaphoric negator, as in the standard, and also of repeating the verb followed by não. This difference is illustrated in (44):

(43) Positive answers (wide-scope yes/no question):

Q: $\quad$ Você tem muitas dívidas? you have many debts

'Do you have many debts?'

A: Tenho (sim).

have.1SG indeed

[oral standard and northern BP]

'Yes.'

(44) Negative answers:

Q: $\quad$ Você tem muitas dívidas?

you have many debts

'Do you have many debts?'

A: $\quad$ a. Não.

no

[oral standard and northern BP]

'No.'
b. Tenho não
have.1SG not
'I do not.'

[northern BP only]

What we see, then, is that the contextually restricted negation pattern observed in northern BP varieties does not challenge the hypothesis in (32), in terms of which languages which draw on a structurally high concord element are not expected to proceed to Stages IV/V of JC. (35c)-type structures are the result of an independent negative reinforcement strategy, which reinforces a particular sub-type of negative structure. As such, (35c)-type structures are comparable to the MSA lexical substitution structures discussed in Section 2.2.2.2: in both cases, the presence of the negative form in question rather than the neutral sentential negator 
signals the emphatic form of a particular type of non-neutral negation (contradictory, contrary, presuppositional, etc.); strikingly, the structures in question can never be interpreted as simple negation structures.

Combining the insights from Afrikaans and BP, then, we see that languages may employ lexical substitution in order to reinforce neutral sentential negators and, crucially, that they may draw on the same lexical resources as those which serve a reinforcement role via doubling in the context of JC. In the BP case, it is possible that the anaphoric negator, não, may have served twice to supply a reinforcer. The first time, não doubled $\mathrm{NEG}_{1}$ (medial $n \tilde{a} o / n \tilde{a} o_{1}$ ) and ultimately became reanalysed as an integrated Pol-head, não $o_{2}$, which now optionally surfaces in emphatic negatives, regardless of their discourse status (new, activated, etc.; cf. Biberauer and Cyrino 2009a for discussion), i.e. BP has a $\mathrm{NEG}_{2}$ element. $^{26}$ Exclusively in northern varieties of BP, não may also have been harnessed a second time, this time specifically in activated contexts, and, quite plausibly, initially in negative short answers of the type illustrated in (44). This second use, which is, crucially, independent of the first, has not produced formal changes to the anaphoric negator and we therefore see the clausefinal element we have labelled $n \tilde{a} o_{3}$ still behaving like the anaphoric negation element which can also surface in isolation. In the general BP case, then, we see an illustration of how a language's NO-element (cf. (23) above) can be harnessed for doubling-type reinforcement, whereafter the possibility of further JC developments arise. In the northern BP case, however, we do not see how a newly created concord element can ultimately take over as a sentential negator; this case, instead, involves an independent, lexical reinforcement choice. Viewed in this way, the systematic discrepancies discussed in the previous section can then be understood straightforwardly: being independent developments, we do not expect the kind of partial continuity that would characterise earlier- and later-stage phenomena associated with a single development.

\subsection{Conclusion}

This section has shown that BP does not, despite superficial appearances to the contrary, constitute a counterexample to the hypothesis in (32). Instead, it is clear that great caution is required in describing negation-related diachronic processes, with lexical substitution options existing alongside JC-style doubling reinforcement strategies and the distinction between the two not necessarily being very clear in all cases owing to the fact that both cyclic and noncyclic reinforcements may draw on the same lexical stock: in Afrikaans, the difference is clear; in northern BP, it is not immediately so. In the diachronic context, awareness of this point is crucial: structures superficially suggesting Stage IV/V developments need to be considered very carefully to determine whether they do indeed represent developments of this type or whether they instead instantiate independent, non-cyclic reinforcement strategies. This is as important a consideration in the context of trying to establish an accurate characterisation

\footnotetext{
${ }^{26}$ It could also be that the final não in (35b)-type structures had its origins in the discourse particle, ne, which functions in exactly the same way as the Afrikaans element in (22a), which coincidentally has the same phonological form. See Biberauer and Cyrino (2009a) for further discussion.

If the anaphoric negator was in fact the source for $n \tilde{a} o_{2}-$ also, of course, a possibility for Afrikaans $n i e_{2}-$ it is worth noting that its integration with the clausal spine would entail downward reanalysis, contrary to what has been proposed for the reanalysis of the "low" concord elements in more familiar languages (BP Pol can be shown to be lower within the CP-domain than its Afrikaans counterpart - cf. Biberauer and Cyrino 2009a for discussion; the anaphoric negator would initially have been adjoined to the highest clausal projection).
} 
of the history of negation for any specific language or group of languages as it is in refining our understanding of the workings of JC.

In this respect, the Afrikaans and BP facts highlight at least two significant points. The first of these is that non-doubling reinforcement strategies that do not ultimately feed into JC, but that do play (discourse-)specific, and possibly only short-lived and non-generalising, negative reinforcement roles are as likely in Stage III languages as in Stage I or II languages (cf. Kiparsky and Condoravdi 2006, Mosegaard Hansen 2009, Larrivée 2010, and Willis et al. 2013 for discussion of doubling reinforcements in Stage I and II languages). The second is that languages which select structurally high elements to serve as reinforcers (Stage II), which then become obligatory concord elements (Stage III), do not seem to proceed to Stage IV as readily as languages in which low reinforcers are reanalysed as concord elements (cf. (32) above).

Before concluding the second main part of this article, we briefly present two further cases which further reinforce the latter point, suggesting that the so-called "Bipartite with Final Negation/BNF" languages may more generally be rather less like well-studied Western European languages than Bell (2004) originally suggested and thus worthy of further systematic investigation.

\section{Further test cases: Santomé and BNF Bantu languages}

In this section, we will very briefly consider the specific case of Santomé, a Portuguese-based Gulf of Guinea Creole, and Bantu languages exhibiting discontinuous negation with a final negator. The discussion in this section draws heavily on data presented in Hagemejier (2007) and deVos and van der Auwera (2013).

\subsection{Santomé}

Santomé permits the same range of negation options as BP, but the status of these options is different. Specifically, the default (or unmarked) pattern involves negative doubling $\left(\mathrm{NEG}_{1} \ldots \mathrm{NEG}_{2}\right)$, i.e. Santomé is a Stage III language, like Afrikaans. Additionally, there are also two marked options, one featuring just $\mathrm{NEG}_{1}$ and the other featuring just $\mathrm{NEG}_{2}$, i.e. the clause-final negator. Crucially, the latter of these marked options is the youngest, with the marked option featuring just $\mathrm{NEG}_{1}$ being the oldest. At first sight, then, it might seem that we are dealing with a language in which the clause-final negator is taking over as the "real" negator (cf. Hagemeijer 2007 for speculations along these lines). The examples in (45) illustrate the negation options in which we are most interested - the doubling structure and $\mathrm{NEG}_{2}$-only structure:

a. $\quad \check{E}$ na sê piskafa.

he not know fish NEG

'He doesn't know how to fish/He can't fish.'

(Hagemeijer 2007: 174)

b. Zon ka fla, glita fa!

Zon ASP speak shout NEG

'Zon speaks; he doesn't shout!'

(Hagemeijer 2007: 189) 
c. Ni glêntu d'awa? Sabi kyê nê fồ!

in inside of-water key fall in-3SG NEG-EMPH

'Into the water? The key didn't fall in there!'

(Hagemeijer 2007: 189)

Although the origins of $f a$ are not entirely $\operatorname{clear}^{27}$, it is striking that the marked $\mathrm{NEG}_{2}$ structures necessarily involve activated contexts (cf. Hagemeijer 2007: 190). They are thus felicitous in the same contexts as the innovative northern BP NEG-final structures involving anaphoric não (nãos above) and Afrikaans g'n structures. Strikingly, as (45c) shows, $f a$ alternates with $f \hat{o}$, which is in fact the more commonly occurring element in $\mathrm{NEG}_{2}$-only structures (cf. Hagemeijer 2007: 189). For reasons which become clearer against the background of the data in (46), this fact is significant in light of what we have seen in connection with northern BP:

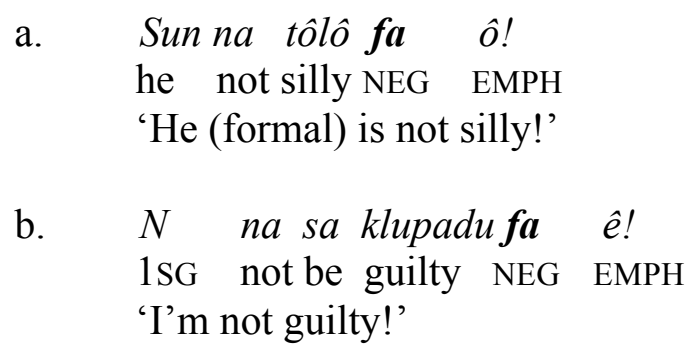

(Hagemeijer 2007: 177)

As these examples clearly show, activated $\mathrm{NEG}_{2}$-only negation structures may also feature so-called "emphasis markers" of various kinds. These elements may also occur independently of $f a$ in strong affirmatives and other contexts, i.e. they may be instantiations of Pol-heads (cf. note 20). The crucial point for our purposes is that the more commonly occurring final element in $\mathrm{NEG}_{2}$-only structures very clearly represents a blend of $f a+\hat{o}$, i.e. it is not simply the reinforcing $f a$ which is obligatory in neutral negatives like (45a); it is a stressed form of this lexical item. Similarly, Hagemeijer (p.c.) confirms that $f a$ in (45b)-type structures may be strongly stressed. Both of these facts strongly recall northern BP não $o_{3}$, suggesting that we may once again be dealing with a case not of progression within $\mathrm{JC}$, but instead of a distinct reinforcement process which happens to draw on the same lexical stock as the earlier JCrelated reinforcement process which led to $f a$ becoming obligatory alongside $n a$. This case, and others involving other Spanish- and Portuguese-based creoles and contact varieties (cf. Lipski 2001), clearly deserve closer investigation.

\subsection{Bantu BNF languages and SVONeg systems}

Another group of languages which deserve closer synchronic and diachronic inspection are the Bantu languages that have drawn on anaphoric negation elements in order to reinforce an initially preverbal negator (generally realised by preverbal morphology; cf. deVos and van der Auwera 2013). What is striking about these languages is that the crosslinguistically very unusual SVONeg order which is strongly represented in central Africa (cf. Dryer 2009) is least common in those zones where double negation (or, more accurately, negative concord; see note 28 for the rationale underlying the retention here of deVos and van der Auwera's

\footnotetext{
${ }^{27}$ A low minimiser, deriving from Portuguese fava ('bean'), has been suggested as a potential source, as has the possibility that $f a$ may have originated as a high discourse-sensitive intensifier (cf. Hagemeijer 2007: 258ff for discussion). The fact that modern-day $f a$ alternates with discourse-sensitive emphasis markers in certain contexts may indicate that it is synchronically a high element, but this matter requires more detailed investigation.
} 
terminology) is most strongly represented. ${ }^{28}$ In fact, three of the four SVONeg regions are not contiguous with double-negation regions, which strongly suggests that SVONeg patterns do not have their origins in BNF structures of the type that have been the focus of this article. In other words, it seems to be the case that SVONeg systems are not the outcome of cyclic JCdevelopments and that the BNF systems involving a high final concord element $\left(\mathrm{NEG}_{2}\right)$ deriving from the anaphoric negator (see below) have not developed into systems where this final element has been reanalysed as a "real" negator $\left(\mathrm{NEG}_{3}\right)$. DeVos and van der Auwera (2013: 216) explicitly note that there is only one language in the double-negation zones, the creole Kituba (classified as H10 in the conventional Bantu classification system), that exhibits SVONeg ordering. Here the final negation marker, ve, derives from the anaphoric negator, but "whether there ever was a pre-initial negative marker in Kituba is doubtful. More likely it concerns an innovative negative strategy, more simple than the double negative strategy used in the [non-creole - TB] Kongo variants [spoken in the region - TB]" (deVos and van der Auwera $i$ bid.). These authors also note a further creole, Lingala (C36d), which likewise seems to have innovated a clause-final negative marker, té. In Bobangi, the non-creole variety by which Lingala is most strongly influenced, té again serves as the anaphoric negation element, and it is additionally used to negate nominal phrases (e.g. no sugar, no money, etc.). In both of these varieties, then, we see an SVONeg pattern that has not derived from an earlier doubling structure in the context of which the final negator was simply a reinforcer. This is what (32) predicts. ${ }^{29}$

In order to determine the extent to which (32) more generally makes the correct predictions about Stage III systems with high, and therefore quite likely, final concord elements, closer investigation of the attested SVONeg languages is necessary. As noted by Reesink (2002) and Dryer (2009), the languages exhibiting this property are located in two major geographical areas: Central Africa, as already mentioned, and the Austronesian islands. Since this pattern is so clearly areal and also is not confined to specific language families within these areas, contact is evidently a relevant consideration. If (32) is a genuine (i.e. inviolable) structural constraint on negative developments, the fact that contact is a factor should, however, not interfere with the predictions made in this article. These cases, then, could potentially provide illuminating controls for the proposals made here.

Also striking in connection with two of the Bantu zones in which double negation is common is that we find systems which exhibit what van der Auwera $(2009,2010)$ calls "tripling" marking of negation via three rather than just two elements (cf. deVos, Tshibanda and van der Auwera 2010, and deVos and van der Auwera 2013 for detailed discussion). This is effectively what we also see in MSA, where it is possible for a clause expressing a single semantic negation to feature $g$ 'n, niks and $n i_{2}$ (cf. (17b) above). In fact, both MSA and some of the relevant Bantu languages also permit quadrupling (cf. (17b) for Afrikaans, and, again, deVos, Tshibanda and van der Auwera 2010, and deVos and van der Auwera 2013). As with

\footnotetext{
28 "Double negation" here refers to discontinuous negation structures of all kinds, with no distinction being made between so-called "post-verbal" systems where the concord element immediately follows the verb (as in standard French) and "post-final" systems, where the concord element follows the clause-final element. As deVos and van der Auwera (op. cit.) show, there are, however, numerous languages in the four doublenegation zones which are post-final.

${ }^{29}$ The reasoning leading to (32) additionally predicts that the final negators in these systems will not be located as high in the structure as the position usually associated with the anaphoric negator (see Section 2.3.2 for discussion). In other words, systems in which the anaphoric negator also serves as the sentential negation marker $\left(\mathrm{NEG}_{1}\right.$ in (1)) must have involved downward grammaticalisation (see also note 26 ).
} 
the Afrikaans cases, these tripling and quadrupling options are restricted by discourse considerations. Again, then, we have evidence of BNF languages employing reinforcement strategies which are very clearly independent of JC. Taken together, the Afrikaans and Bantu cases (and also the case of the Vanuatu language, Lewo, discussed in van der Auwera (2009)) suggest that tripling may be a relatively natural consequence in Stage III languages, which neutrally require negative doubling. The extent to which tripling rather than progression to Stage IV/V is natural in these languages is a matter that, to date, has not been investigated in detail, but, in the context of the findings discussed in this article, it does appear to be one which merits systematic attention.

Having completed our discussion of the theoretical and empirical matters arising from the diagnosis of Afrikaans's concord-marking nie as an unusually high negation-related element, we now turn our attention to the matter of Afrikaans's position in the broader context of negation typology.

\section{Afrikaans in the broader typological context}

What we have seen in Section 2 above is that Afrikaans differs from familiar Western European Negative Concord (NC) languages like French in respect of the structural properties of its sentential negation markers: while the "real" negator seems to be located in roughly" the position of West Germanic sentential negation markers more generally (see note 17), the concord element is significantly higher up in the structure. In this section, we will briefly consider how the Afrikaans negation system as a whole can be understood in relation to the types familiar from the generative literature (cf. Biberauer and Zeijlstra 2012a,b for more detailed discussion).

In negation terms, languages are commonly divided into those in which negative elements each contribute their own semantic negation - so-called "Double Negation (DN) languages", standard English and Dutch being cases in point - and those in which this is not (consistently) the case - so-called "Negative Concord (NC) languages". The latter have been shown to take various forms, with a particular distinction having been drawn between so-called "Strict NC languages" and "Non-Strict NC languages" (cf. Giannakidou 1997, 2000, 2006, and see Zeijlstra 2004 for discussion and references). The distinction is illustrated in (47-48), with Czech exemplifying the Strict NC system, and Italian the Non-Strict system (all examples are taken from Zeijlstra 2008, and Biberauer and Zeijlstra 2012a,b):
a. Milan nevolá.
Milan NEG.calls
'Milan doesn't call.'
b. Dnes nikdo nevolá.
today nobody NEG.calls
'Today nobody is calling.'

\footnotetext{
${ }^{30}$ There are indications - i.a. from scrambling phenomena (cf. Louw 2012) - that Afrikaans $n i e_{l}$ may also not be located in the same position as Dutch niet. This matter requires further investigation, however.
} 


\section{c. Milan nevidi nikoho. \\ Milan NEG.sees nobody \\ 'Milan doesn't see anybody.'}

(48) a. Gianni non telefona a Marco.

Gianni NEG calls to Marco

'Gianni doesn’t call Marco.'

b. Ieri nessuno ha telefonato a nessuno.

yesterday nobody has called to nobody

'Yesterday nobody called anybody.'

c. Gianni non telefona a nessuno.

Gianni NEG calls to nobody

'Gianni doesn't call anybody.'

As the examples show, Strict $\mathrm{NC}$ requires the realisation of the sentential negation marker (ne- in Czech) in all negative sentences, regardless of whether it additionally contains negative indefinites (like nikdo and nikoho in (47)) or not. By contrast, Non-Strict NC only requires the presence of the sentential negation marker (non in Italian) where it is independently marking sentential negation (48a) or where there is no other preverbal negative element (48c); where the subject is negative, non is barred (at least in neutral structures; cf. Biberauer and Zeijlstra 2012a for discussion). This distributional asymmetry leads Zeijlstra $(2004,2008)$ to propose that Strict and Non-Strict NC languages differ in respect of the featural specifications associated with their core negation-marking lexical elements. More specifically, since negative-marked elements can never independently express semantic negation in Strict NC languages, he proposes that these elements are semantically and formally non-negative; in the (minimalist) framework he employs, this entails a featural specification of [uNEG], i.e. the presence of an uninterpretable negative feature. As there are structures in which negative-marked elements can independently contribute a semantic negation to the structures of which they are a part without their being present in every negative sentence (contrast $n e$ - and non in this respect), Zeijlstra analyses Non-Strict NC languages as having both semantically negative and semantically non-negative negative elements. More specifically, he proposes that the sentential negation marker, non, is semantically negative and thus specified [iNEG] (i.e. it bears an interpretable negation feature), while negative indefinites are semantically non-negative, and thus bear [uNEG]. Non-Strict NC languages, then, resemble DN languages like standard English and Dutch in featuring negative-marked elements (the sentential negator non) that contribute their own negative meaning, i.e. elements specified [iNEG]; all negation-marked elements in standard English and Dutch are assumed to be [iNEG], with the result that NC is systematically ruled out. At the same time, they resemble Strict NC languages in having negative-marked elements (negative indefinites) that are not intrinsically negative, i.e. elements specified [uNEG]. This analysis produces the negation typology in (49): 
(49) Negation typology couched in terms of semantic (non-)negativity ([i/uNEG])

\begin{tabular}{|l|c|c|}
\hline & $\begin{array}{l}\text { Semantically negative } \\
\text { Negative Indefinites }\end{array}$ & $\begin{array}{l}\text { Semantically non- } \\
\text { negative Negative } \\
\text { Indefinites }\end{array}$ \\
\hline $\begin{array}{l}\text { Semantically } \\
\text { negative sentential } \\
\text { negation markers }\end{array}$ & DN languages (Dutch) & $\begin{array}{c}\text { Non-Strict NC languages } \\
\text { (Italian) }\end{array}$ \\
\hline $\begin{array}{l}\text { Semantically non- } \\
\text { negative sentential } \\
\text { negation markers }\end{array}$ & $? ? ?$ & $\begin{array}{c}\text { Strict NC languages } \\
\text { (Czech) }\end{array}$ \\
\hline
\end{tabular}

The missing system in (49) is the inverse of the Non-Strict NC system in Italian, i.e. an NC system in which the sentential negation marker is semantically non-negative ([uNEG]), while negative indefinites are semantically negative ([iNEG]). Expressed in terms of the NC types identified by den Besten (1986, 1989), what distinguishes the missing system from the other NC systems is the absence of Negative Spread, i.e. co-occurring negative indefinites producing a single negative meaning; the other NC systems both have Negative Spread. Since sentential negation always (with the exception of the haplology contexts; cf. note 4) requires the presence of clause-final $n i_{2}$, we know that Afrikaans meets the missing system's [uNEG] requirement on sentential negation markers; further, since negative indefinites do not, standardly, combine to produce a single negation (i.e. Negative Spread), we can see that it also meets the [iNEG] requirement on negative indefinites. The examples in (50) illustrate these facts:

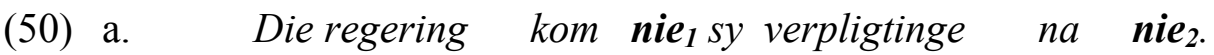
the government come not his responsibilities after POL 'The government is not meeting its responsibilities.'

b. Niemand het niks gebring nie 2 . no-one have nothing brought POL

'No-one brought nothing.', i.e. everyone brought something

In other words, standard Afrikaans instantiates the missing type in (49). Strikingly, this type seems to be very rare indeed, and the only other system that has been said to instantiate it is (a time-limited stage of) Old High German (cf. Jäger 2008).

Viewed in acquisition terms, it is not hard to understand why the standard Afrikaans negation system may well be, crosslinguistically, extremely rare. Consider the following putative learning pathway (SM signifies sentential negation elements and NIs negative indefinites): 


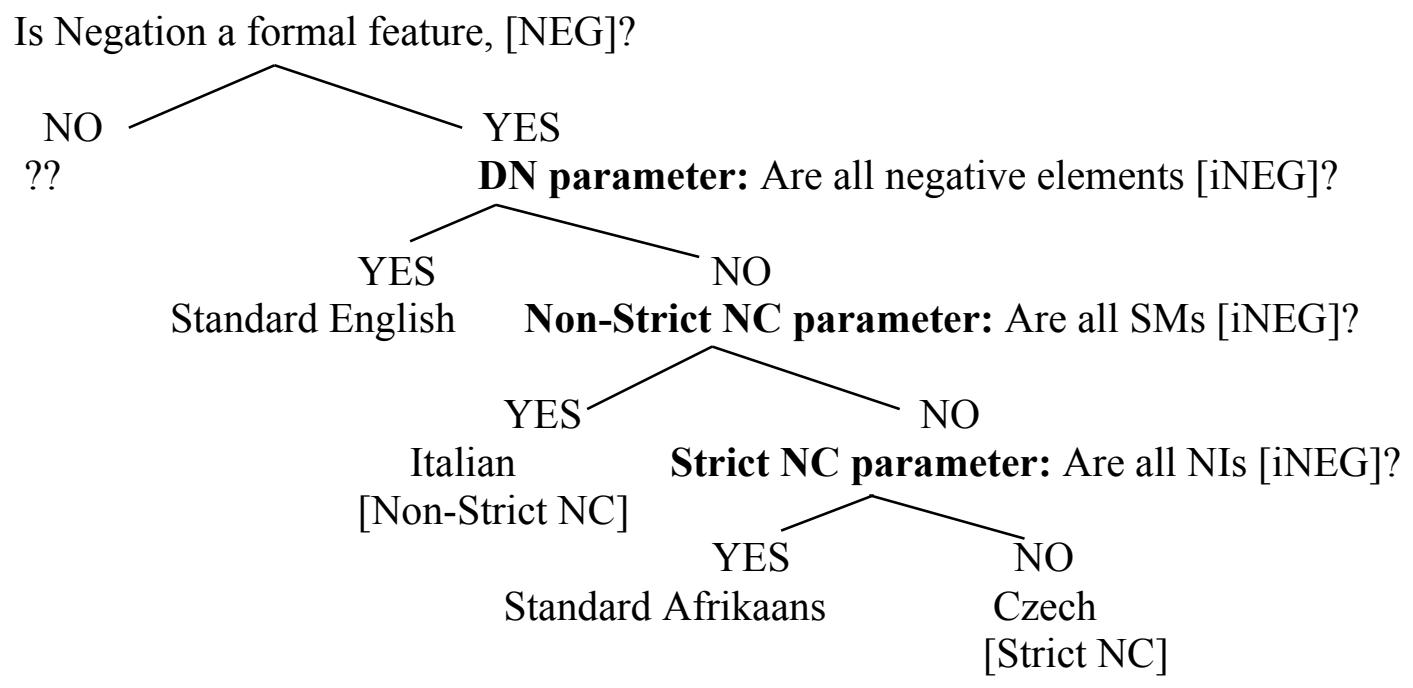

Here, the idea is that acquirers first have to establish whether negation plays a role in structuring the syntactic system, i.e. is it necessary to refer to the feature [negation] to understand a syntactic regularity (e.g. movement or agreement or ellipsis, etc.) in the system? (Cf. Biberauer 2011, 2015, 2016 for more detailed discussion of the empirical diagnostics indicating the presence of an active formal feature ${ }^{31}$.) To the best of our knowledge, there is no language in which negation is not present as a formal feature, [negation], hence ?? under the NO option associated with the initial question. That [negation] is active in DN languages like English is immediately evident from i.a. the fact that this feature plays a role in defining one of the so-called "residual V2" contexts in the language (Never in my life had I heard such a preposterous idea!) and also from the fact that it triggers do-support (I do not believe it! vs *I not believe it!). ${ }^{32}$ It is very evidently active in NC languages by virtue of the fact that it triggers $\mathrm{NC}$, which is a species of syntactic agreement.

${ }^{31}$ Biberauer (2011 et seq.) proposes an emergentist approach to the acquisition of formal features, departing from the standardly held Chomskyan assumption that acquisition requires "a one-time selection" of UG-given formal features (pace Chomsky 2001: 10). It is worth noting that the empirical diagnostics she proposes to identify the presence of specific formal features in the syntactic system are, in principle, independent of this broader emergentist agenda; they could also be viewed as the basis on which acquirers endowed with the more generally accepted UG-given inventory establish which formal features are active in the systems they are acquiring. A theory trying to pin down the basis on which this linking/mapping occurs is a necessary component of any fully worked out generative account of language acquisition, but there has never, to my knowledge, been a very concerted attempt to work out the details of such a theory.

${ }^{32}$ In fact, on the Polarity-oriented analysis of $d o$-support mentioned in passing in note 20 (cf. also Duffield 2007, 2013), it is not even clear that standard English is so straightforwardly a DN language: if do is an obligatory Pol-head, as Duffield (op. cit.) and Biberauer and Roberts (2015) argue, standard English negation is in fact $\mathrm{NC}$, showing an at first non-obvious parallel with Afrikaans NC. This is schematised in (i):
(i) a. Afrikaans NC: $\quad n i e_{1} \ldots n_{2} e_{2}$ where $n i e_{2}$ is structurally higher than $n i e_{1}$, i.e. Pol $>\mathrm{Neg}$ NEG POL
b. $\quad$ Standard English NC: do ... not where do is structurally higher than $n o t$, i.e. Pol $>$ Neg POL NEG

If this is correct, the fact that non-standard Englishes so frequently develop prescriptively barred NC structures (That ain't not gonna help me - 'That isn't going to help me' and He didn't do nothing - 'He didn't do anything') may actually be a reflex of this being "more natural" in the context of the basic sentential negation system, which is already NC. As will become clear in the main text, a very similar consideration appears to be in play in (standard and non-standard) Afrikaans. 
Once the acquirer has established the presence of [negation] in the system, the question that arises is whether the overt lexical items in the system are associated with semantically negative [negation] features (i.e. [iNEG]) or not ([uNEG]). For the purposes of our discussion here, we will assume that the simplest system will be the one in which all negative-marked items are [iNEG], i.e. a DN system like standard English or Dutch. The reasoning here is that [iNEG] instantiates the "strongest" value of the formal feature [negation], i.e. one which is not only significant in the syntactic derivation (what minimalists call "Narrow Syntax"), but which is also interpretively significant at the semantic/LF interface (alongside the phonological/PF one, given that the elements we are considering are necessarily negativemarked in some morphophonological way). It is worth noting that the absence of a "strength" bias of the kind we are proposing here might render an initial question about the distribution of [uNEG]- rather than [iNEG]-features equally plausible. If the input steers the acquirer in the postulation of feature-oriented questions, as Biberauer (2011 et seq.) assumes, it may well be that the $[\mathrm{iNEG}] /[\mathrm{uNEG}]$ focus of the initial question on the learning path differs, depending on whether the acquirer is encountering a $\mathrm{DN}$ or an $\mathrm{NC}$ system. For ease of exposition, we leave this matter aside here (see Biberauer 2015 for discussion).

On the assumption that sentential negation will be very frequent indeed in the input - i.a. also in the context of negative imperatives ${ }^{33}$ - it seems reasonable to assume that the acquirer will in effect be making the initial [iNEG]-related decision on the basis of consideration of the sentential negation marker(s) in the target system. Where these are [iNEG], the default assumption will be that all negative-marked elements in the system are [iNEG]; this is what Biberauer (2011 et seq.) terms "Input Generalisation", i.e. make maximal use of a formal feature that has been identified in the input (cf. Roberts 2007 for the original, more restricted formulation of this idea). ${ }^{34}$ If there is evidence to the contrary, the acquirer will seek to restrict the original domain of elements assumed to bear [iNEG], assuming that it is only sentential negation markers (SMs) that bear this feature. This delivers Non-Strict NC languages like Italian. If this assumption, too, turns out to be unwarranted, the child will assume all overtly negative-marked elements to be [uNEG], thus accounting for the postulation of Strict NC languages like Czech.

What is unclear, then, is how a child will draw the conclusion that the target system has the standard Afrikaans profile, i.e. [iNEG] negative indefinites and [uNEG] sentential negation markers. Assuming Input Generalisation is to play a key role in the acquisition process, it is clear that the acquirer will be biased towards generalising [uNEG] once (s)he has established that sentential negation elements are [uNEG]. Input Generalisation is, of course, always defeasible by the input, so the question that arises is whether there is any input that would allow a child who has identified [uNEG] sentential negation markers in their target language

33 Biberauer $(2015,2016)$ argues that imperatives and interrogatives constitute particularly important components of the acquisition input, not only by virtue of their frequency, but also because these structures provide the acquirer with particularly syntax-rich structures that allow acquirers to establish which formal features are fundamental to the systems they are acquiring. Consider the numerous formal differences between positive and negative imperatives, or between interrogatives and "basic" declaratives, or between polarity- and answerseeking questions, for example. These differences are argued to alert the acquirer to the presence of relevant formal features, facilitating the subsequent identification of further formal features in the system, and thus accounting for how an acquirer may determine precisely which formal features make up the target language.

34 For Biberauer (2011 et seq.), Input Generalisation is an acquisition bias, i.e. the reflex of what Chomsky (2005) terms a "third factor", where the relevant third factor is the general cognitive bias to Make Maximal Use of Minimal Means. See Biberauer $(2015,2016)$ for more discussion. 
to overrule Input Generalisation and postulate [iNEG] negative indefinites. DN structures like (50b), involving two or more negative indefinites, each of which contributes its own semantic negation, would seem to be the obvious answer here. Leaving aside the rarity in the input of these marked structures (Horn 1989), a further difficulty is the fact that NC languages also permit them and, moreover, do so under the same marked circumstances and exhibiting the same marked intonation pattern - Liberman and Sag's so-called "contradiction contour" (cf. i.a. Corblin et al. 2004, Rooryck 2008, Biberauer 2009, Huddlestone 2010, and Biberauer and Zeijlstra 2012b for discussion). As such, there is no primary linguistic data that will ever help the acquirer to distinguish between a Strict NC language and an Afrikaans-type system, with the result that we would expect acquirers always to stick with the simpler system, i.e. the Strict NC one, in terms of which all negatively marked elements are uniformly [uNEG]. If that is correct, standard Afrikaans negation cannot be acquired only on the basis of the input and it also does not appear to be a system that can be acquired even if we take "third factor" considerations into account (as we have just seen, Input Generalisation, a linguistic reflex of the third factor bias to Make Maximal Use of Minimal Means, militates again its postulation). This implies that standard Afrikaans negation is not a natural grammatical system. For it to be learned, external input is required. That this is not entirely implausible is suggested by the fact that Afrikaans speakers seem to readily permit Strict NC-type negative-indefinite-containing structures like those illustrated in (52):

(52) a. Niemand het niks gebring nie $_{2}$. no-one have nothing brought POL 'No-one brought anything.' ～(contrast DN (50b) above)

b. Ons hoor nooit niks van die polisie nie 2 . us hear never nothing from the police POL 'We never hear anything from the police.'

(Beeld newspaper 2004-02-24, cited in Huddlestone 2010: 142)

The exception to this generalisation about the acceptance of (52)-type structures are speakers with very strong prescriptive instincts: these speakers insist on the (50b)-type DN readings for the structures in (52), showing that the crosslinguistically very rare standard Afrikaans system is indeed one that defines the grammars of a subset of speakers. As Beatrice Santorini (p.c.) observes, Negative Spread-type NC is particularly salient in "logically" oriented prescriptive traditions more generally, there very clearly being two or more identifiably negative elements which should each contribute their own semantic negation. This means that we can realistically expect acquirers to receive Direct Negative Evidence highlighting the deviant nature of (52)type Negative Spread structures and thus allowing them to learn a standard Afrikaans-type NC system. If this is all on the right track, this means that the standard Afrikaans negation system is, in part, acquired L2-style, on the basis of explict metalinguistic input (cf. Meisel, Elsig and Bonnesen 2011 for discussion of a similar situation in the acquisition of modern French, another system known to be regulated by strong prescriptive traditions). Without this intervention, Afrikaans negation would, like that of many other languages crosslinguistically, take the form of a Strict NC system ${ }^{35}$; thanks, however, to the prescriptive intervention of the advocates of the

35 It is worth noting that modern-day Dutch varieties that are (residually) NC (e.g. West Flemish; cf. i.a. Haegeman 1995; Breitbarth and Haegeman 2010, 2014) and also those Belgian varieties likewise permitting optionally reinforcing negative elements paralleling the use of "extra" nie $_{2}$ discussed in Section 2.2.2.1, are precisely ones that permit Negative Spread, i.e. two or more negative indefinites being given an NC 
Afrikaans Taalbeweging, who insisted on imposing an NC sentential negation component on an originally consistently DN system (cf. our discussion of Dutch above, and also note 14), it is something exotic and, ironically, not entirely natural.

\section{Conclusion}

This article has considered three distinct but related questions, all of which have the modern Afrikaans negation system as their point of departure. First, we sought to establish what underlies the peculiarity of Afrikaans's distinctive clause-final negative concord element, $n i e_{2}$. This element was argued to differ substantially from familiar Western European concord elements in being drawn, as Roberge (2000) first proposed, from a very different lexical source, namely a structurally high resumptive element, which, significantly, has been incorporated into the modern system as an element that still occupies a very high position in the clausal domain - one, in fact, that suggests that recent efforts to extend the standardly assumed clausal architecture are on the right track. This element appears to be inert in the context of Jespersen's well-known Cycle, serving a range of concord functions, also in contexts lacking specifically negative elements and in non-clausal contexts. Closer inspection further reveals that there are various negative-reinforcement developments taking place in modern Afrikaans, but that none of these are leading to the strengthening of nie ${ }_{2}$. Given the existence of a semantically motivated interface constraint on structurally very high elements acting as sentential negators (cf. Han 2001), we considered the Biberauer (2009, 2012a) hypothesis that systems with concord markers located in or above the CP-domain will fail to undergo Stage III-IV/V developments within the Jespersenian Cycle.

This hypothesis formed the centrepiece of the second part of the article, in which the hypothesis was put to the test on the basis of data from Brazilian Portugese, Santomé and a subset of Bantu systems. Initial consideration of these systems would seem to suggest that the prediction may be correct: none of the systems considered seem to have a structurally high final negation element that is serving or is developing into the basic sentential negation marker. If this holds more generally in languages with final negation markers - which we might expect, in part, to derive from structurally high elements like anaphoric negators or discourse-oriented resumptives ${ }^{36}$ - detailed investigation of Afrikaans will have highlighted a previously unnoticed constraint on cyclic developments, namely that it is possible to "grammaticalise beyond the cycle".

Finally, the focus returned to Afrikaans specifically, and we considered this language's negation system in the context of negation typology and learnability matters. Yet again, the conclusion that seems to emerge is that the Afrikaans negation system is only superficially similar to more familiar Western European models. More specifically, it would seem to be the case that the mix of "exotic" contact considerations and ideologically motivated prescriptive

interpretation; cf. again Aelbrecht (2008a,b), van der Auwera and Neuckermans (2004), and van der Auwera et al. (2006). Here too, then, Input Generalisation might plausibly have played a role, producing an extension of a pattern detectable in one domain to others in which it was not initially evident (see Zeijlstra 2004 on the strongly DN nature of standard Dutch). Precisely which NC pattern - Negative Doubling or Negative Spread - might have constituted the starting point for these distributions represents an interesting question that would merit further research. In light of our discussion in Sections 2-4 about marked negation doubling contexts i.e. doubling (NC) which only takes place in marked negative structures - it could, of course, be that there is no direct connection between these NC patterns.

${ }^{36}$ Though see deVos and van der Auwera (2013) for discussion of lower alternatives, e.g. locatives and possessives. 
intervention at the standardisation stage has produced a system that children cannot straightforwardly acquire. As indicated in this article, all of the key questions discussed here would merit further investigation. What does seem clear, however, is that Afrikaans negation, as Hans den Besten always said, is nie sommer nie!

\section{References}

Aelbrecht, L. 2008a. Negatieverdubbeling in Vlaamse spreektaal. Over Taal 47(1): 6-9.

Aelbrecht, L. 2008b. Niemand nie in Vlaamse spreektaal. TABU 26(3/4): 89-103.

Alcázar, A. and M. Saltarelli. 2014. The syntax of imperatives. Cambridge: Cambridge University Press.

Alkmim, M. 1999. Ação de dois fatores externos no processo de mudança em negativas sentenciais no dialeto mineiro. Anais do II Congresso Nacional da ABRALIN, Florianópolis.

Alkmim, M. 2001. As negativas sentenciais no dialeto mineiro: uma abordagem variacionista. Doctoral dissertation: Universidade Federal de Minas Gerais.

Alkmin, M. 2002. Negativa pré e pós-verbal: implementação e transição. In M. Cohen and J. Ramos (Eds.) Dialeto mineiro e outras falas. Belo Horizonte: FALE/UFMG. pp.169-182.

Armstrong, M. and S. Schwenter 2008. Prosody, accessibility, and sentential negation in Brazilian Portuguese. Proceedings of the Berkeley Linguistics Society (BLS) 34(1): 379-390.

Van der Auwera, J. 2009. The Jespersen Cycles. In E. van Gelderen (Ed.) Linguistic cycles. Amsterdam: Benjamins. pp. 35-71.

Van der Auwera, J. 2010. On the diachrony of negation. In L. Horn (Ed.) The expression of negation. Berlin: Mouton. pp. 73-101.

Van der Auwera, J. and A. Neuckermans. 2004. Jespersen's Cycle and the interaction of predicate and quantifier negation in Flemish. In B. Kortmann (Ed.) Typology meets dialectology. Dialect grammar from a crosslinguistic perspective. Berlin: Mouton. pp. 454478 .

van der Auwera, J., L. de Cuypere and A. Neuckermans. 2006. Negative indefinites: A typological and diachronic perspective on a Brabantic construction. In T. Nevalainen, J. Klemola and M. Laitinen (Eds.) Types of variation. Diachronic, dialectal and typological interfaces. Amsterdam: Benjamins. pp. 305-319.

Bayer, J. 2009. Nominal negative quantifiers as adjuncts. Journal of Comparative Germanic Linguistics 12: 5-30.

Bell, A. 2004. Bipartite Negation and the Fine Structure of the Negative Phrase. Doctoral dissertation, Cornell University. 
Den Besten, H. 1977/1983. On the interaction of root transformations and lexical deletive rules. In W. Abraham (Ed.) On the formal syntax of the West Germania. Amsterdam: Benjamins. pp. 47-131.

Den Besten, H. 1986. Double negation and the genesis of Afrikaans. In P. Muysken and N. Smith (Eds) Substrata versus universals in creole genesis. Amsterdam: Benjamins. pp. 185230 .

Den Besten, H. 1989. Studies in West Germanic Syntax. Doctoral dissertation, University of Tilburg.

Biberauer, T. 2008. Doubling and omission: Insights from Afrikaans negation. In S. Barbiers, O. Koeneman, M. Lekakou and M. van der Ham (Eds.) Microvariations in syntactic doubling. Bingley: Emerald. pp. 103-140.

Biberauer, T. 2009. Jespersen off course? The case of contemporary Afrikaans negation. In E. van Gelderen (Ed.) Linguistic cycles. Amsterdam: Benjamins. pp. 91-130.

Biberauer, T. 2011. In defence of lexico-centric parametric variation: Two $3^{\text {rd }}$ factorconstrained case studies. Paper presented at the Workshop on Formal Grammar and Syntactic Variation: Rethinking Parameters (Madrid).

Biberauer, T. 2012a. Competing reinforcements: When languages opt out of Jespersen's Cycle. In A. Van Kemenade and N. de Haas (Eds.) Historical Linguistics 2009: Selected papers from the 19th International Conference on Historical Linguistics, Nijmegen, 10-14 August 2009. Amsterdam: Benjamins. pp. 1-30.

Biberauer, T. 2012b. Predicate doubling in (Germanic) contact varieties: Introducing the case of Afrikaans. Paper presented at the $27^{\text {th }}$ Comparative Germanic Syntax Workshop (Yale).

Biberauer, T. 2015. Macro- and microvariation: An emergentist perspective. Paper presented at the Formal Approaches to Morphosyntactic Variation conference (Vitoria).

Biberauer, T. 2016. Syntactic variation, stability and change: An emergentist parametric perspective. Paper to be given at the Royal Netherlands Academy of Arts and Sciences 'Language variation in action' Colloquium (Amsterdam, 19 February).

Biberauer, T. Forthcoming. Particles and the Final-over-Final Constraint. To appear in T. Biberauer, A. Holmberg, I. Roberts and M. Sheehan (Eds.) The Final-over-Final Constraint. Cambridge, MA: MIT Press.

Biberauer, T. and S. Cyrino. 2009a. Negative developments in Afrikaans and Brazilian Portuguese. Paper presented at $19^{\text {th }}$ Colloquium on Generative Grammar (Vitoria).

Biberauer, T. and S. Cyrino. 2009b. Appearances are deceptive: Jespersen's Cycle from the perspective of the Romania Nova and Romance-based creoles. Paper presented at Going Romance (Nice). 
Biberauer, T. and I. Roberts. 2011. Negative words and related expressions: A new perspective on some familiar puzzles. In R. Ingham and P. Larrivée (Eds). The evolution of negation: Beyond the Jespersen Cycle. Berlin: de Gruyter. pp. 23-60.

Biberauer, T. and I. Roberts. 2015. Rethinking formal hierarchies: A proposed unification. In J. Chancharu, X. Hu and M. Mitrović (Eds.) Cambridge Occasional Papers in Linguistics 7: $1-31$.

Biberauer, T. and I. Roberts. In press. Parameter typology from a diachronic perspective: The case of Conditional Inversion. To appear in E. Bidese, F. Cognola and M. Moroni (Eds.) Aspects of variational linguistics. Amsterdam: Benjamins.

Biberauer, T. and H. Zeijlstra. 2012a. Negative Concord in Afrikaans: Filling the typological gap. Journal of Semantics 29(3): 345-371.

Biberauer, T. and H. Zeijlstra. 2012b. Negative changes: Three factors and the diachrony of Afrikaans negation. In C. Galves, S. Cyrino, R. Lopez and J. Avelar (Eds.) Parameter theory and linguistic change. Oxford: Oxford University Press. pp. 237-263.

Breitbarth, A. 2009. A hybrid approach to Jespersen's Cycle in West Germanic. Journal of Comparative Germanic Linguistics 12(2): 81-114.

Breitbarth, A. and L. Haegeman. 2010. Continuity is change: The long tail of Jespersen's Cycle in Flemish. In A. Breitbarth, C. Lucas, S. Watts and D. Willis (Eds.) Continuity and change in grammar. Amsterdam: Benjamins. pp. 61-76.

Breitbarth. A. and L. Haegeman 2014. The distribution of preverbal en in (West) Flemish: Syntactic and interpretive properties. Lingua 147: 69-86.

Camargos, M.L. 2002. Teoria de Cópia e Negação. MA dissertation, Universidade Federal de Minas Gerais.

Cardinaletti, A. and M. Starke. 1999. The typology of structural deficiency: A case study of the three classes of pronouns. In H. van Riemsdijk (Ed.) Clitics in the languages of Europe. Berlin: Mouton de Gruyter. pp. 145-233.

Cavalcante, R. 2007. A negação pós-verbal no Português Brasileiro: Análise descritiva e teórica de dialetos rurais de afro-descendentes. MA dissertation, Universidade Federal da Bahia.

Chomsky, N. 2001. Derivation by phase. In M. Kenstowicz (Ed.) Ken Hale: A life in language. Cambridge, MA: MIT Press. pp. 1-53.

Chomsky, N. 2005. Three factors in language design. Linguistic Inquiry 36: 1-22.

Cinque, G. 1999. Adverbs and functional heads: A crosslinguistic perspective. Oxford: Oxford University Press. 
Corblin, F., V. Déprez, H. de Swart and L. Tovena. 2004. Negative Concord. In F. Corblin and H. de Swart (Eds.) Handbook of French semantics. Stanford: CSLI Publications. pp. 417452 .

Dahl, Ö. 2001. Inflationary effects in language and elsewhere. In J. Bybee and P. Hopper (Eds.) Frequency and the emergence of linguistic structure. Amsterdam: Benjamins. pp. 471480.

Deumert, A. 2002. Standardization and social networks: The emergence and diffusion of standard Afrikaans. In A. Linn and N. McLelland (Eds.) Standardization. Amsterdam: Benjamins. pp. 1-25.

Deumert, A. 2004. Language standardization and language change: The dynamics of Cape Dutch. Amsterdam: Benjamins.

DeVos, M. and J. van der Auwera. 2013. Jespersen cycles in Bantu: Double and triple negation. Journal of African Languages and Linguistics 34: 205-274.

DeVos, M., M. Tshibanda and J. van der Auwera. 2010. Jespersen Cycles in Kanincin: Double, triple and maybe even quadruple negation. Africana Linguistica 16: 155-182.

Diesing, M. 1992. Indefinites. Cambridge, MA: MIT Press.

Donaldson, B. 1993. A grammar of Afrikaans. New York: Mouton de Gruyter.

Duffield, N. 2007. Aspects of Vietnamese clausal structure: Separating tense from assertion. Linguistics 45(4): 765-814.

Duffield, N. 2013. On polarity emphasis, assertion and mood in English and Vietnamese. Lingua 137: 248-270.

Dryer, M. 1996. Focus, pragmatic presupposition, and activated propositions. Journal of Pragmatics 26(4): 475-523.

Dryer, M. 2009. Verb-Object-Negative order in Central Africa. In N. Cyffer, E. Ebermann and G. Ziegelmeyer (Eds.) Negation patterns in West Africa. Amsterdam: Benjamins. pp. 307-362.

Du Toit, S.J. 1876/1897. Eerste beginsels van die Afrikaanse taal. Fergelijkende taalkunde fan Afrikaans en Engels. Paarl: D.F. du Toit \& Co.

Eckardt, R. 2006. Meaning change in grammaticalization. An enquiry into semantic reanalysis. Oxford: Oxford University Press.

Fonseca, H.D.C. 2004. Marcador negativo final no Português Brasileiro. Cadernos de estudos lingüísticos 46(1): 5-19.

Van Gelderen, E. 2004. Grammaticalisation as economy. Amsterdam: Benjamins. 
Van Gelderen, E. 2009. Cyclical change. Amsterdam: Benjamins.

Van Gelderen, E. 2011. The linguistic cycle: Language change and the language faculty. Oxford: Oxford University Press.

Giannakidou, A. 1997. The Landscape of Polarity Items. Doctoral dissertation, University of Groningen.

Giannakidou, A. 2000. Negative ... Concord? Natural Language and Linguistic Theory 18: 457-523.

Giannakidou, A. 2006. N-words and Negative Concord. In M. Everaert and H. van Riemsdijk (Eds.) The syntax companion (volume 3). Oxford: Blackwell. pp. 327-391.

Giorgi, A. 2010. About the speaker. Towards a syntax of indexicality. Oxford: Oxford University Press.

Grimshaw, J. 1991. Extended Projection. Unpublished ms: Brandeis.

Grohmann, K. 2003. Prolific domains: On the anti-locality of movement dependencies. Amsterdam: Benjamins.

Haeberli, E. 2011. Looking high and low for NegP in early English. In P. Larrivée and R. Ingham (Eds.) The evolution of negation. Beyond the Jespersen Cycle. Berlin: Mouton de Gruyter. pp. 115-144.

Haegeman, L. 1995. The syntax of negation. Cambridge: Cambridge University Press.

Haegeman, L. and V. Hill. 2013. The syntacticization of discourse. In R. Folli, R. Truswell and C. Sevdali (Eds.) Syntax and its limits. Oxford: Oxford University Press. pp. 370-390.

Han, C.-H. 2001. Force, negation and imperatives. The Linguistic Review 18: 289-325.

Hagemeijer, T. 2007. Clause Structure in Santomé. Doctoral dissertation, University of Lisbon.

Hansen, Q. 2009. Negation in Brazilian Portuguese. Ph.D. proposal, University of Florida.

Holmberg, A. 2015. Verb Second. In T. Kiss and A. Alexiadou (Eds.) Theory and analysis. An international handbook. Berlin: Mouton de Gruyter. pp. 242-283.

Holmberg, A. 2016. The syntax of yes and no. Oxford: Oxford University Press.

Horn, L. 1989. A natural history of negation. Chicago: University of Chicago Press.

Huddlestone, K. 2010. Negative Indefinites in Afrikaans. Doctoral dissertation, Utrecht University. 
Hugo, D. (Ed.) 2009. Halala Afrikaans. Pretoria: Protea Publishers.

Ingham, R. 2007. NegP and negated constituent movement in the history of English. Transactions of the Philological Society 105(3): 1-33.

Israel, M. 1996. Polarity sensitivity as lexical semantics. Linguistics and Philosophy 19(6): 619-666.

Israel, M. 1997. The scalar model of polarity sensitivity: The case of the aspectual operators. In D Forget, P. Hirschbühler, F. Martineau and M.-L. Rivero (Eds.) Negation: Syntax and semantics. Amsterdam: Benjamins. pp. 209-230.

Israel, M. 2001. Minimizers, maximizers, and the rhetoric of scalar reasoning. Journal of Semantics 18(4): 297-331.

Jäger, A. 2008. History of German negation. Amsterdam Benjamins.

Jespersen, O. 1917. Negation in English and other languages. Copenhagen: A.F. Høst.

Van Kemenade, A. 2000. Jespersen's Cycle revisited: Formal properties of grammaticalization. In S. Pintzuk, G. Tsoulas and A. Warner (Eds.) Diachronic syntax: Models and mechanisms. Oxford: Oxford University Press. pp. 51-75.

Van Kemenade, A. 2011. Secondary negation and information structure organization in the history of English. In P. Larrivée and R. Ingham (Eds.) The evolution of negation. Beyond the Jespersen Cycle. Berlin: Mouton de Gruyter. pp. 77-114.

Kiparsky, P. and C. Condoravdi. 2006. Tracking Jespersen's Cycle. In M. Janse, B. Joseph and A. Ralli (Eds.) Proceedings of the $2^{\text {nd }}$ International Conference of Modern Greek Dialects and Linguistic Theory. Mytilene: Doukas. pp. 172-197.

Laka, I. 1990. On the Syntax of Negation. Doctoral dissertation, MIT.

Laka, I. 1994. On the syntax of negation. New York: Garland.

Lam, Z. 2014. A complex ForceP for speaker- and addressee-oriented discourse particles in Cantonese. Studies in Chinese Linguistics 35: 62-78.

Larrivée, P. 2010. The pragmatic motifs of the Jespersen Cycle: Default, activation, and the history of negation in French. Lingua 120(9): 2240-2258.

Lipski, J. 2001. Strategies of double negation in Spanish and Portuguese. Unpublished ms: Penn State. Available online: http://www.personal.psu.edu/jml34/negation.pdf (Accessed 26 January 2016).

Louw, F. 2012. Scrambling in Afrikaans. MA dissertation, University of Kwazulu-Natal. 
Martínez, C. 2013. Negation in Vernacular Brazilian Portuguese. Doctoral dissertation, University of Texas.

Martins, E.E. 1997. Sentential negation in spoken Brazilian Portuguese. Washington: Georgetown University Press.

Meisel, J., M. Elsig and M. Bonnesen. 2011. Delayed grammatical acquisition in first language development: Subject-verb inversion and subject clitics in French interrogatives. Linguistic Approaches to Bilingualism 1(4): 347-390.

Meisner, C., E. Stark and H. Völker (Eds.) 2013. Jespersen Revisited. Lingua 147 (special edition).

Molnárfi, L. 2002. Die Negationsklammer im Afrikaans: Mehrfachnegation aus formaler und funktionaler Sicht. In W. Abraham and J.-W. Zwart (Eds.) Issues in formal German(ic) typology. Amsterdam: Benjamins. pp. 223-261.

Mosegaard Hansen, M.-B. 2009. The grammaticalization of negative reinforcers in Old and Middle French: A discourse-functional approach. In M.-B. Mosegaard Hansen and J. Visconti (Eds.) Current trends in diachronic semantics and pragmatics. Bingley: Emerald. pp. 227251.

Mosegaard Hansen, M.-B. and J. Visconti (Eds.) 2014. The diachrony of negation. Amsterdam: Benjamins.

Oosthuizen, J. 1998. The final nie in Afrikaans negative sentences. Stellenbosch Papers in Linguistics 31: 61-94.

Paesani, K. 2006. The case of special registers. In L. Progovac, K. Paesani, E. Casielles and E. Barton (Eds.) The syntax of nonsententials. Multidisciplinary perspectives. Amsterdam: Benjamins. pp. 147-182.

Paul, I. 2007. Missing topics in Malagasy headlines. Proceedings of the 2007 Annual Conference of the Canadian Linguistic Association. Available online: http://homes.chass.utoronto.ca/ cla-acl/actes2007/Paul.pdf (Accessed 26 January 2016).

Pauwels, J. 1958. De expletieve ontkenning nie(t) aan het einde van de zin in het Zuidnederlands en het Afrikaans. In J. Pauwels. Het dialect van Aarschot en omstreken. Bouwstoffen en studiën voor de geschiedenis en de lexicografie van het Nederlands. Brussel: Belgisch Interuniversitair Centrum voor Neerlandistiek.

Poletto, C. 2008a. On negative doubling. Quaderni di Lavoro ASIt 8: 57-84.

Poletto, C. 2008b. The syntax of focus negation. University of Venice Working Papers in Linguistics 18: 181-202.

Ponelis, F. 1993. The development of Afrikaans. Duisburg: Peter Lang. 
Ramchand, G. 2008. Verb meaning and the lexicon. Cambridge: Cambridge University Press.

Reesink, G. 2002. Clause-final negation: Structure and interpretation. Functions of Language 9(2): 239-268.

Van Rensburg, C. 2012. So kry ons Afrikaans. Pretoria: Lapa.

Rizzi, L. 1997. On the fine structure of the left periphery. In L. Haegeman (Ed.) Elements of grammar. Dordrecht: Kluwer. pp. 281-338.

Robbers, K. 1992. Properties of negation in Afrikaans and Italian. Linguistics in the Netherlands 9(1): 223-234.

Roberge, P. 1994. The formation of Afrikaans. Stellenbosch Papers in Linguistics 23: 1-110.

Roberge, P. 2000. Etymological opacity, hybridization, and the Afrikaans brace negation. American Journal of Germanic Linguistics and Literatures 12(1): 101-176.

Roberts, I. 2007. Diachronic syntax. Oxford: Oxford University Press.

Roberts, I. 2010. Grammaticalization, the clausal hierarchy, and semantic bleaching. In E. Traugott and G. Trousdale (Eds.) Gradience, gradualness and grammaticalization. Amsterdam: Benjamins. pp. 45-73.

Roberts, I. and A. Roussou. 2003. Syntactic change: A minimalist approach to grammaticalization. Cambridge: Cambridge University Press.

Rooryck, J. 2008. A Compositional Analysis of French Negation. Unpublished ms: Leiden.

Ross. J.R. 1970. On declarative sentences. In R.A. Jacobs and P.S. Rosenbaum (Eds.) Readings in English Transformational Grammar. Waltham, MA: Ginn \& Co. pp. 222-272.

Schwartz, B. and S. Vikner. 1996. The verb always leaves IP in V2 clauses. In A. Belletti and L. Rizzi (Eds.) Parameters and functional heads: Essays in comparative syntax. Oxford: Oxford University Press. pp. 11-62.

Schwegler, A. 1986. Analyticity and syntheticity: A diachronic perspective with special reference to Romance languages. Berlin: de Gruyter.

Schwegler, A. 1991. Predicate negation in contemporary Brazilian Portuguese: A linguistic change in progress. Orbis 34: 187-214.

Schwenter, S. 2002. Fine-tuning Jespersen's Cycle. In B. Birner \& G. Ward (eds). Drawing the boundaries of meaning: Neo-Gricean studies in Semantics and Pragmatics in honor of Laurence R. Horn. Amsterdam: Benjamins. pp. 327-344.

Schwenter, S. 2005. The pragmatics of negation in Brazilian Portuguese. Lingua 115: 14271456. 
Sigurðsson, H. 2004. The syntax of Person, Tense, and speech features. Italian Journal of Linguistics 16: 219-251.

Teixeira de Sousa, L. 2011. Sentential negation in Brazilian Portuguese: Pragmatics and syntax. JournaLipp 1: 89-103.

Teixeira de Sousa, L. 2013. Sentential negation at the syntax-prosody interface. Revista Estudos Linguísticos 17(2): 1-19.

Speas, M. and C. Tenny. 2003. Configurational properties of point of view roles. In A.-M. di Sciullo (Ed.) Asymmetry in grammar volume 1: Syntax and semantics. Amsterdam: Benjamins. pp. 315-343.

Steyn, J.C. 2014. 'Ons gaan ' $n$ taal maak'. Afrikaans sedert die PATRIOT-jare. Brandfort: Kraal Uitgewers.

Stowell, T. 1991. Empty Heads in Abbreviated English. Unpublished ms: GLOW handout.

Tenny, C. 2000. Core events and adverbial modification. In C. Tenny andc J. Pustejovsky (Eds.) Events as grammatical objects. Stanford: CSLI Publications. pp. 285-334.

Valkhoff, M. 1966. Studies in Portuguese and Creole, with special reference to South Africa. Johannesburg: Witwatersrand University Press.

Vinet, M.-T. 1993. L'aspect et la copule vide dans la grammaire des titres. Langue française 100: 83-100.

Wallage, P. 2005. Negation in Early English: Parametric Variation and Grammatical Competition. Doctoral dissertation, York University.

Westergaard, M. 2009. The acquistion of word order. Micro-cues, information structure, and economy. Amsterdam: Benjamins.

Weir, A. 2009. Article Drop in English Headlinese. MA dissertation, UCL.

Willis, D. 2013a. Negation in the history of the Slavonic languages. In D. Willis, C. Lucas and A. Breitbarth (Eds.) The history of negation in the languages of Europe and the Mediterranean. Volume 1: Case studies. Oxford: Oxford University Press. pp. 341-398.

Willis, D. 2013b. The history of negation in the Brythonic Celtic languages. In D. Willis, C. Lucas and A. Breitbarth (Eds.) The history of negation in the languages of Europe and the Mediterranean. Volume 1: Case studies. Oxford: Oxford University Press. pp. 239-298.

Willis, D., C. Lucas and A. Breitbarth. (Eds.) 2013. The history of negation in the languages of Europe and the Mediterranean. Volume 1: Case studies. Oxford: Oxford University Press. 
Wiltschko, M. 2015. The (not so) silent syntax of speech acts and their participants: A comparative perspective. Paper presented at the $4^{\text {th }}$ Cambridge Comparative Syntax conference (Cambridge, UK).

Van der Wouden, T. (Ed.) 2012. The roots of Afrikaans. Selected writings of Hans den Besten. Amsterdam: Benjamins.

Zanuttini, R. 1997. Negation and clausal structure: A comparative study of Romance languages. Oxford: Oxford University Press.

Zeijlstra, H. 2004. Sentential Negation and Negative Concord. Doctoral dissertation, University of Amsterdam.

Zeijlstra, H. 2008. Negative Concord is Syntactic Agreement. Unpublished ms, University of Amsterdam. Available online: Lingbuzz/000645 (Accessed 26 January 2016). 